\title{
Historical and linguistic perspectives on fortified settlements in Southeastern Wallacea: Far eastern Timor in the context of southern Maluku
}

\author{
Antoinette Schapper
}

The remains of fortified settlements in far eastern Timor have attracted the attention of archaeologists and led to speculation regarding the underlying drivers of fortification. In this paper, I draw attention to the fact that fortified settlements were not a localised development in far eastern Timor, but in fact are characteristic of a large swathe of southern Maluku. Using evidence from the historical record and from language, I contend that fortified settlementbuilding cannot be attributed to particular climatic or socioeconomic conditions but is best understood as a cultural feature diffused on a regional level.

\section{Introduction $^{1}$}

The landscape of the eastern tip of the island of Timor features numerous stone-walled structures in strategic positions. Investigation has revealed the most significant of these to be the remains of old fortified settlements. In the flurry of academic activity that the eastern part of the island has seen in the last decade, these fortified settlements have become the subject of several studies. Out of this work has arisen an academic debate about the forces driving the construction of these fortified settlements. One side has argued that severe climatic conditions in the period after $1000 \mathrm{BP}$ led to shortages of food, which in turn created a need to defend critical settlements with good access to water for crop irrigation. Those on the other side have countered that the dating of the fortifications does not correlate with the relevant palaeoclimatic events known to have taken place in the region, and argue instead that social changes surrounding the arrival of European colonial powers are likely to have driven the conflict that necessitated the building of village fortifications.

\footnotetext{
1 Support for this research has been gratefully received from a Netherlands Organisation for Scientific Research VENI project 'The evolution of the lexicon: Explorations in lexical stability, semantic shift and borrowing in a Papuan language family', by the Volkswagen Stiftung DoBeS project 'Aru languages documentation', and by the Australian Research Council project (ARC, DP180100893) 'Waves of Words'. Many thanks to Toos van Dijk, Roy Ellen, Aone van Englenhoven, Hans Hägerdal, Juliette Huber, Timothy Usher and Emilie T.B. Wellfelt for their generosity in providing me with much useful information and data from their areas of expertise. All errors are my own.
} 


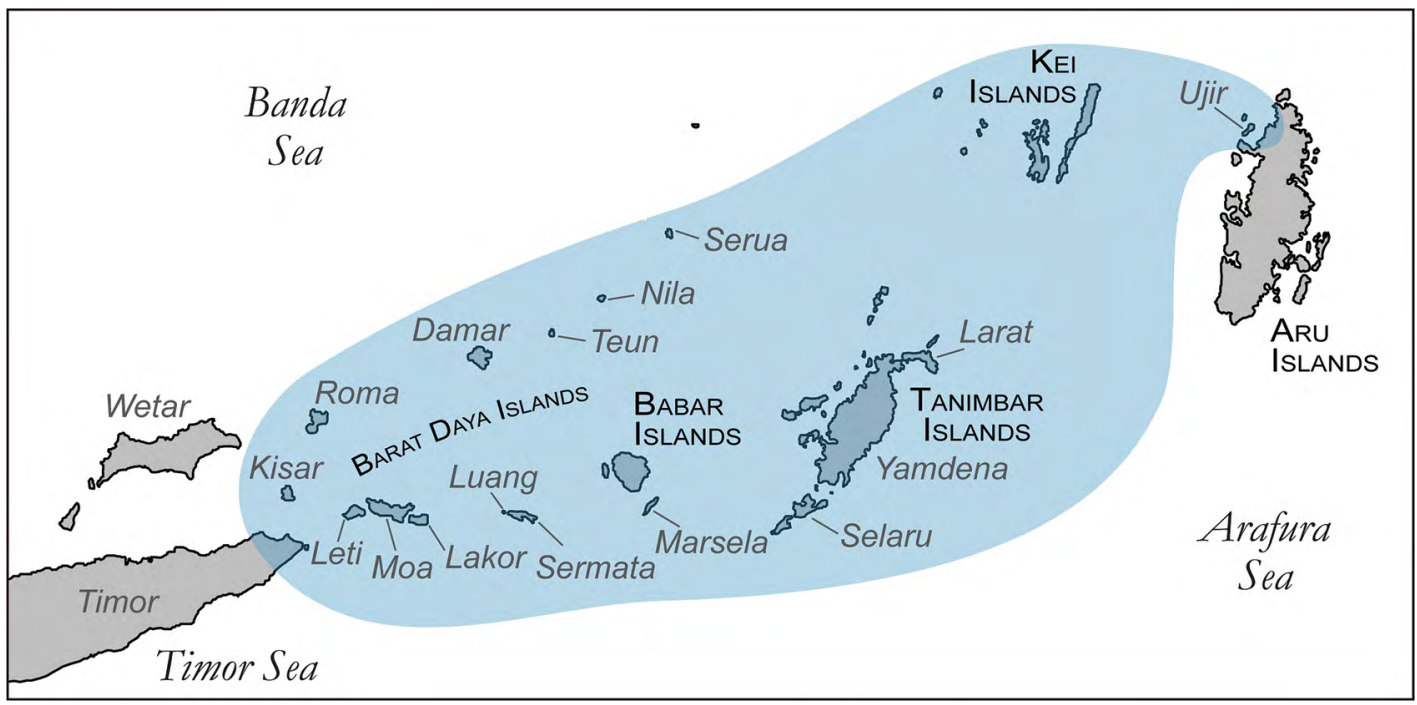

Figure 10.1. Area of southern Maluku and eastern Timor where fortified villages are concentrated (shaded blue).

Source: Antoinette Schapper.

Yet to be considered in this debate is the larger picture of fortified settlement-building in the region beyond the far eastern tip of Timor. Fortified settlements were not a localised development in eastern Timor where specific historical climatic or social conditions held. Fortifications were built widely across the Indonesian archipelago, but stone walls fortifying villages are found with particular concentration in the island region that takes in the southern Moluccan islands from Kisar to Kei (Figure 10.1). That adjacent regions such as the far eastern Tutuala region of Timor and the west coast of Aru also present this settlement pattern historically is highly suggestive of a phenomenon that has diffused from group to group over the region.

In this paper, I contend that fortified settlement-building was a regional phenomenon that spread across southern Maluku, probably during the seventeenth and eighteenth centuries. There are striking similarities across this region in the stone walls fortifying villages, the words used for them and the ways in which they were used and conceptualised. Using descriptions and images from the historical record, I outline the distribution of fortified settlements and paint a picture of their construction and function. Using evidence from language, I show that the term \#lutuR, denoting a wall built up from stones, shows signs of borrowing across the region. This indicates that stone wall-building itself, along with the vocabulary with it, diffused across the region. I suggest that as one group built a wall around its village, neighbouring groups were prompted to protect themselves in a similar way. The endemic culture of warfare meant that there was a strong compulsion to adopt village fortifications, thus creating the particular concentration of stone village fortifications attested to in historical accounts and physical remains of which are still visible across the region today.

\section{Fortifications in far eastern Timor-Leste}

Archaeological investigation in the eastern half of the island of Timor has seen a flourishing since the declaration of East Timor's independence in 2002. A focal point of activity has been the area at the eastern extreme of the island. While small wall structures are observable across the whole of Timor, this far eastern region is notable for evidencing the archaeological remains of numerous large fortified settlements. This has given rise to a two-sided academic debate about the historical origins and drivers of village fortification. 
On the one side, Lape (2006), Lape and Chao (2008) and Chao (2008) have with increasing elaboration put forward the idea that the emergence of village fortification is related to climate change. They argue that El Niño events causing severe climatic conditions, in particular, variable rainfall, would have led to food shortages. This in turn, they argue, occasioned the building of fortifications in areas with valuable water resources for the growing of crops, as groups sought to protect their resources from raiders coming from the surrounding regions. Lape and Chao admit, however, that the dating of the fortified village sites to the period 1450-AD 1650 does not correspond with the known El Niño frequency peak at AD 1300-1400.

Picking up on the lack of dating correlation, an interdisciplinary team out of The Australian National University have disputed Lape and Chao's climate-induced fortification model. O'Connor et al. (2012) bring together a large number of radiocarbon dates from excavations of fortified villages, confirming that settlement activity was only initiated in them from the midfourteenth century onwards, too late for that El Niño-driven drought model of Lape and Chao. As an alternative climate-driven model, O'Connor et al. (2012) consider the post-AD 1300 climate transition observed by Nunn (2007) on the basis of examples in the Pacific. In Nunn's (2007) work, it is proposed that the rise of fortification in the Pacific is associated with extended droughts following from changes in monsoon patterns after the transition from the Medieval Warm period to the Little Ice Age from AD 1250-1350. While Nunn (2007) does not discuss East Timor, O'Connor et al. (2012) remark that only the last few decades of the period of widespread climate change in the Nunn model coincide better with the beginning of fortification in East Timor than Lape and Chao's model. However, in the absence of palaeoclimate data for East Timor, the only impact of the Little Ice Age on East Timor that O'Connor et al. (2012) can perceive is a slight lowering of temperatures. This, they conclude, would not have been likely to cause substantial changes in East Timor.

Given the lack of known environmental changes that could have resulted in unpredictability in resource availability, O'Connor et al. (2012) turn to a consideration of social factors that could have given rise to conflict, necessitating the building of fortified settlements. They suggest the following social drivers: population growth arising out of the introduction of maize, slave raiding, competition for valuable trade items such as sandalwood and beeswax, and possibly other unknown internal social developments within the relevant polities in eastern Timor. McWilliam (Chapter 6, this volume) elaborates on O'Connor et al. (2012) and provides more historical argumentation around the proposed social factors that may have initiated and reproduced fortification in eastern Timor. He highlights that this period of fortification aligns with the period of immense economic and social upheaval precipitated by the arrival of Portuguese and then Dutch trading interests, and by the rise of the powerful South Sulawesi trading polities. McWilliam argues that most significant impacts on Timorese social relations and livelihoods were felt from a boom in sandalwood trading from the late sixteenth century, the introduction of maize as a staple food crop in the same period, the new trade in firearms and a significant increase in demand for trade in human slaves. While admitting that the impact on these events on local groups in Timor cannot be tracked with precision, McWilliam suggests that they may well have promoted fortified settlement strategies. However, why the village fortifications are geographically limited to the far eastern part of Timor and not dispersed widely over the whole of the island, where all of these social factors were at play, is not explained.

In sum, for all proposals of drivers of village fortification that we have currently, there remain significant problems in establishing a convincing causal relationship. The climate change-driven models either do not show the right temporal sequencing or cannot be shown to have had an impact that would have effected resource unpredictability, while the suggested social drivers are general factors that were transformative for large swathes of eastern Timor, not simply the areas in which fortifications were found, and whose specific impact on far eastern Timor has not been established. 


\section{Historical descriptions of fortified settlements in southern Maluku}

While documentary history about the area of far eastern Timor may be lacking for much of the period before the twentieth century (as contended by Lape 2006), the adjacent region of southern Maluku was frequented by Europeans in search of spices and other valuable goods from the sixteenth century and is well-described by numerous visitors from that time. While fortified villages in far eastern Timor are not documented in the historical record during the time of their occupation, they are described in southern Maluku where village fortification was in use until the twentieth century. So even though the archaeology in the region is limited and the construction dates of the fortifications remain to be investigated, the historical record provides a picture of the extent and function of stone fortifications around villages in southern Maluku.

The following sections are comprised of a selection of the written and pictorial sources describing and illustrating the fortified villages in the different island groups of southern Maluku. Most sources available on them come from the late nineteenth and early twentieth centuries. Following this period, village fortifications rapidly became obsolete, as the Dutch colonial powers increasingly exercised control over and imposed stability on the islands. ${ }^{2}$

\section{Kei Islands}

Throughout the Kei Islands, villages were once surrounded by sizeable square-shaped stone fortifications topped with hidden gates accessible only via steep ladders:

The form of these fortifications is everywhere the same. Four strong, thick walls, each 50 to $100 \mathrm{~m}$ long, surround a square enclosure. Each wall has in its centre a concealed entrance with stairs, except where a steep adjacent slope makes approach impossible. The ancestors of the Kei people have provided them with prodigious works of this kind, assembling huge blocks of stone into walls a fathom thick and metres in height. (Geurtjens 1921a:270)

In times of war, the walls would be heightened with bamboo and the gates barricaded and lila canons put in place (Riedel 1886:225).

Fortified villages appear to have been found widely in the Kei Islands from the middle of the nineteenth century. The resident of Amboina, J.G.F. Riedel in his wide-ranging (1886) work on the people of Maluku and beyond describes villages in Kei located in inaccessible places surrounded by walls made of coral blocks (my bolding):

With a few exceptions on the islands of Nuhujuut and Nuhutut, the villages of the Kei archipelago are located on the coast in places where water is available. In the past, people say, ... they were built on mountaintops and high cliffs, for fear of enemy attack ... The villages, the biggest of them containing 60 houses, are surrounded by thick coral stone walls (lutur, wat lutur). (Riedel 1886:225)

By the beginning of the twentieth century much of the stone fortification around villages had been removed. In his visit in 1908, the German naturalist Merton found the fortifying walls with steep ladders for entry still in use in a few villages of the mountainous interior (see Figure 10.2).

Half way up we came to a mountain village surrounded by a stone wall several meters high; at the point of entry stood two wide ladders inside and outside the wall. The interior space was divided by lower walls, 1 to $1.5 \mathrm{~m}$ tall, into rectangular courtyards belonging to the individual houses. (Merton 1910:186)

2 The following overview of historical records on stone buildings in southeast Maluku was earlier published in Schapper (2019). 


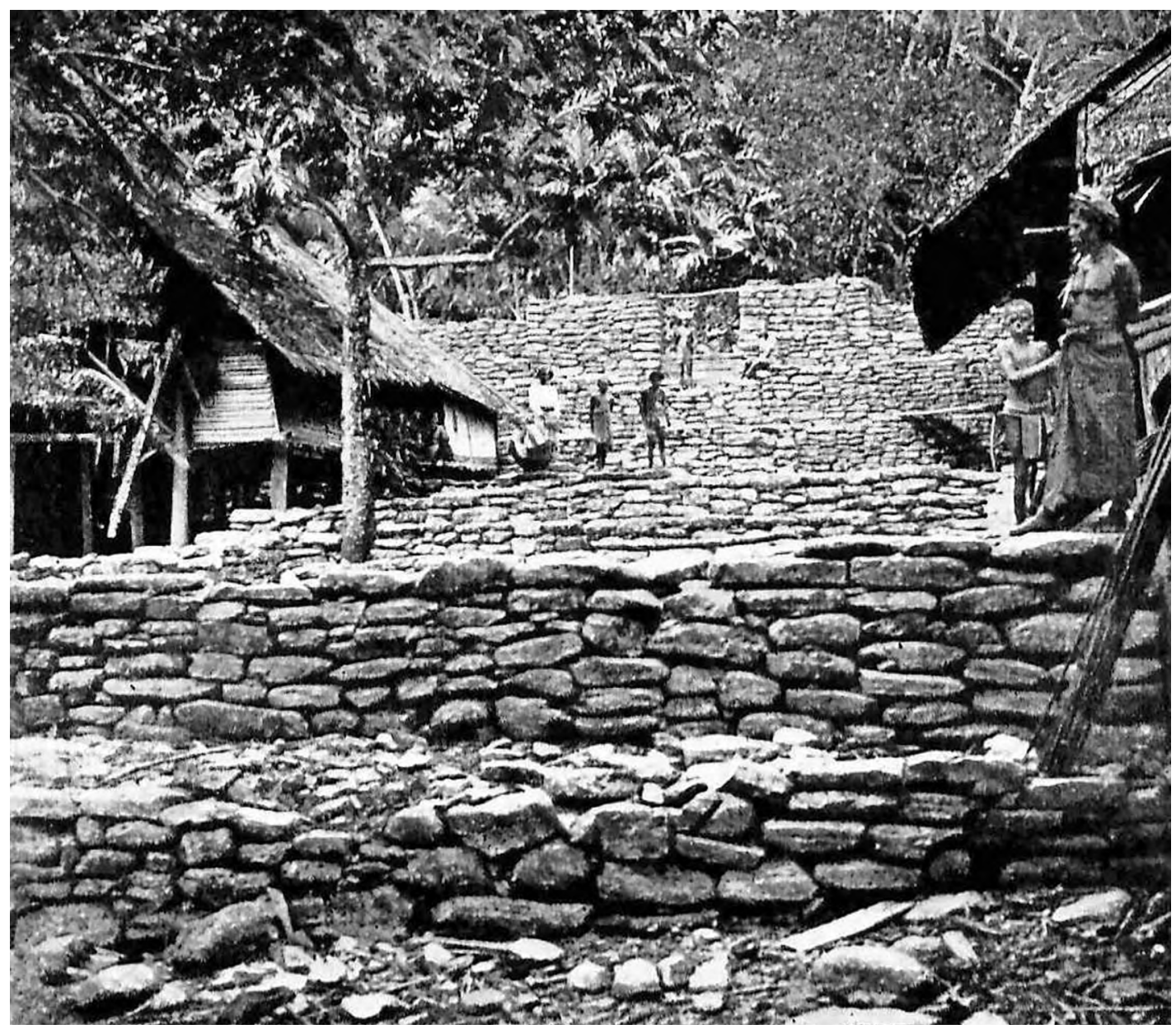

Figure 10.2. Layers of stone walls leading up to the gate of a fortified village in the mountains of the Kei Island.

Source: Hugo Merton, 1910.

Little more than a decade later, the Dutch missionary Geurtjens describes the village fortifications as a thing of the past on the Kei Islands:

In the past, by contrast, the state of war was the norm and the villages were adapted to this situation. Today, peaceful villages can be seen nestling among the greenery in the finest locations along the coast. Formerly they could be found only in the most inaccessible places. It was the steepest of slopes, the most jagged of cliffs, and the grimmest of gorges that made a site suitable for the location of a village. Every village was a fortress, and everybody desired to build a stronghold that would keep the most formidable enemy out. (Geurtjens 1921a:270)

As noted above by Geurtjens, the past state of perpetual warfare between villages was seen to have necessitated the fortifications. Riedel gives an example of the feeble grounds that would lead to war between villages and describes the ritualised way in which the path to war was paved:

The reason for wars are: appropriation of land, insult, and adultery between inhabitants of different villages, including cases in which when a woman who has married into a strange village is insulted there and sends to her blood relatives a benaat meak or token of disgrace, consisting of a little kabus (seed fluff of the Eriodendron anfructuosum) and some manuwuun (chicken feathers), wrapped in a piece of old linen. When a village has decided to wage war, ravuun, its chief sends the chief of the other village a piece of gabagaba called a banaat karvevan, in the form of a sword. If the opposite party does not accept the challenge, the gabagaba is returned. But if the other village wants war, an iron machete is sent back in its place. (Riedel 1886:233) 
Against this background of readiness to warfare, village walls would have played an important role. Being near indestructible to a native force, they would have meant that very little life would be lost in a conflict. The people of Kei viewed the walls as living entities that, although not demanding, did required tending lest their wrath be awakened:

In Kei warcraft and history there is no mention of the destruction or capture of such fortifications ... It was in fact impossible to take one using Kei weapons. The walls were guardians on whom one could depend for one's safety. No wonder, then, that the thoroughly animistic Kei people viewed their defensive wall as an animated being, a living protector, who furthermore also provided accommodation for the protecting spirits of the tribe. The wall itself was not terribly demanding, and it did not require sacrifices, but if one dared to breach or damage it, then there would be reason to fear its revenge. (Geurtjens 1921a:271-272)

Geurtjens (1921a) recounts that the process of removing walls as part of Dutch pacification precipitated predictions of pestilence now that villages had been 'murdered' and 'unclothed':

Smallpox, plague and famine would devour the spirits of the wrongdoers, for they had murdered the old walls, destroyed the homes of the spirits: they had stripped their village, torn up its sarong and left it naked and disgraced before the whole world ... (Geurtjens 1921a:272)

\section{Aru Islands}

Unlike Kei, village fortification was not extensive in Aru. Riedel (1886) notes that, aside from the Dutch-built fort and the attached village of Wokam, there were only two villages with stone fortifications in the Aru Islands in the nineteenth century: Fangabel and Ujir. From as early as the mid-seventeenth century these two villages were in alliance with one another and acted as middlemen for trade between merchants from further west, especially the Makassarese, and the peoples on the eastern side of Aru, with their dense forests populated with birds of paradise and rich seas plentifully supplied with pearls and tortoiseshell (Schapper 2018). Fangabel is no longer inhabited; we have no historical descriptions of the village and there has been no archaeological investigation of the site. ${ }^{3}$ By contrast, Ujir stands out in writings on Aru for the vast complex of stone ruins that it is home to.

The first visitor account of the stone structures in Ujir comes from the Dutchman Kolff on his visit in 1825 . In particular, he describes the ruins of a stone wall that appeared once to surround the village:

During our stay here I inspected the environs of the village and saw some former fortifications, the remains of which show that they must once have been very extensive. We also saw traces of a long street, lined by walls, running from the east to the west through the whole village. Here and there we also saw many ruins of stone houses. (Kolff 1828:233)

Almost two decades later, Brumund was equally impressed by Ujir's ruins on his visit in 1843 . He also observed the high wall around the village and the stone houses overgrown with plants:

The village is ringed by a stacked coral stone wall 6 to 8 feet in height, within which still other walls are to be found. There are also some stone houses, all of which are however in ruins, overgrown with bushes and plants. Among these stand the currently occupied houses with their gabagaba roofs, such that the whole scene resembles the ruins of an ancient city that was laid to waste, among which some vagrants have set up camp. These ruins plainly show, as people also confirmed to me, that Ujir was once much richer and more populous. (Brumund 1845:82-83)

3 Villagers from nearby Samang said in 2018 that there were no stone structures known at the site of the old village of Fangabel. They observed that it is possible that stones could have been taken from the site for building new structures elsewhere. 
Merton also remarked on the extensive stone rubble on his visit to Ujir in 1908. Like Brumund before him, Merton observed not just ruins but also noted that there were many stone walls in use in Ujir village similar to those he saw in Kei:

The village was itself surrounded by stone walls, and in many cases, the land belonging to a house was also delimited from the neighbouring one by walls, just as we later often saw on the Kei islands. (Merton 1910:166)

The origins of these, at least partially, ruined stone walls observed in the nineteenth and twentieth centuries appear to have been a network of fortifications around Ujir village. These fortifications were encountered by Dutch military forces that attacked Ujir in 1789 as part of reprisals for an assault on the Dutch fort on nearby Wokam. The commander of the expedition against Ujir, Adrianus Anthony's Gravessande, failed in his attempt to take the village, explaining in his report that the heavy walls surrounding the village, along with the Ujirese guns, booby trapping and barricading of entry points, could not be overcome: ${ }^{4}$

The matter would have been concluded most favourably, if the Alfurs and Backshore people, who appeared in large numbers and joined us, had dared to fight and not been too afraid not only of the enemy (had they been in the forests and fields, [the Alfurs and Backshore people] would have undertaken to haul them out from there!), but also of the guns and strong fortifications (bentengs) with which the Ujirese have amazingly strengthened their village, a settlement which nature has helped so extraordinarily [due to its protected position inside a creek] ...

Afterwards our people attacked the negeri Ujir for the second time with some fervour, and closed in on the bentengs so strongly, that they shot the Ujirese Jaffoera, son of the orangkaya of Fangabel Abdul, [and] pulled him from it and took his head; [they] subsequently scaled the second and third of the already mentioned bentengs. Some of the enemy fell, among them one person was seen withdrawing to the temple who, judging from his clothing and the circumstances, was considered to be their so-called king Manoeffa who would be Nuku's brother. On this occasion, none of our people fell but several were wounded. Meanwhile, the caltrops with which the ground was littered, the blocking of the roads with felled trees, and the particularly sly damming up of the river created many obstacles for our men. Further circumstances meant that the enemy was in an advantageous position. Other apparent dangers forced us not to go any further, but rather retreat so that the fleet was loaded with suffering wounded people, and not in the condition to go to Goram but had to return. (VOC Archives, VOC 3864, Banda, Secret letters, Report, Banda to Batavia, 4-6$1789, \$ 12)$

The Dutch launched two further expeditions against Ujir, eventually taking the village (Tijdschrift voor Nederlandsch Indië 1858). As part of the terms of peace in 1793, the Ujirese were forced to dismantle all but the most essential of their fortifications (Bataviaasch Genootschap van Kunsten en Wetenschappen 1874). One of the most significant lutur that remained was that which formed the base of the old mosque (Figure 10.3). The archaeology teams who have visited Ujir suggested that this wall was a repurposing of an original fortified structure (O'Connor et al. 2007).

4 Many thanks to Hans Hägerdal for sharing this document and his transcription of it with me. 


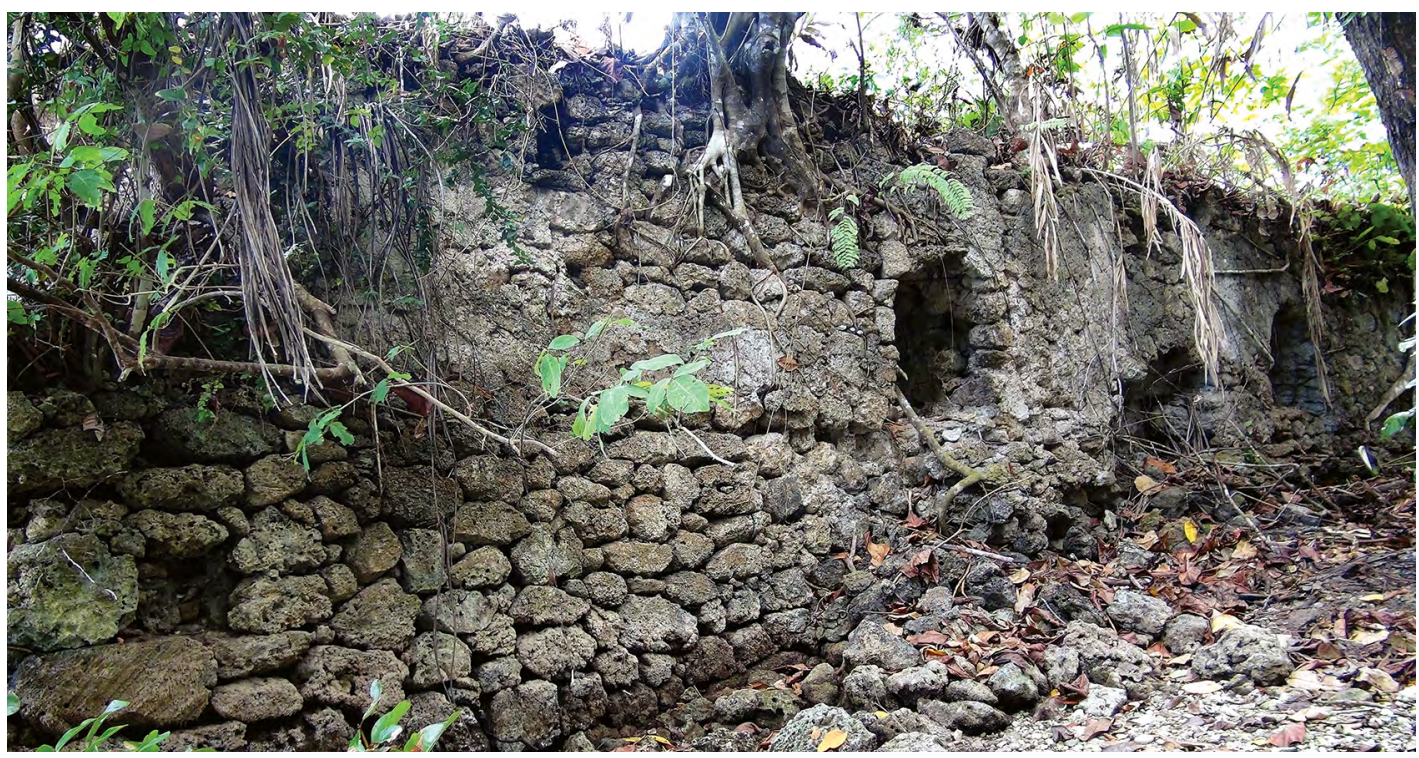

Figure 10.3. The thick, more than $2 \mathrm{~m}$ high lutur, or stone wall, that made up the base of mosque of the old Ujir village and which doubled as a fortification, located strategically at the water's edge. Source: @ Emilie T.B. Wellfelt.

\section{Tanimbar Islands}

Numerous visitors were struck by the heavily fortified villages of the Tanimbar Islands. Accounts of stone walls in Tanimbar take in the main island of Yamdena as well as the satellite islands of Selaru, Larat and Fordata. Riedel describes the fortifications around Tanimbarese villages as follows (my bolding):

On the islands of Yamdena and Selaru, fear of enemy attacks means that villages are built by preference on the peaks of raised coral rocks, up to $120 \mathrm{~m}$ above sea level. Here access is provided by heavy wooden ladders (ret) about $2 \mathrm{~m}$ in width. In time of war these ladders are dismantled and stored in the village. These villages, the largest of which contains eighty big wooden houses standing on piles two to three meters high, are surrounded by heavy walls (lutur) of stacked coral stones, and further protected by palisades of thorny bamboo, while on the seaward side they are usually shielded by Pisonia alba trees. (Riedel 1886:285).

Extensive village fortifications were necessitated by the perpetual state of inter-village warfare that existed in Tanimbar. A picture of the extent can be developed by the accounts of successive travellers to the island of Larat in northern Tanimbar. The English naturalist Forbes stayed in the village of Ritabel in 1882 and encountered many signs of endemic violence:

The next sight was less exhilarating- on a tree-clad elevation the half-burned and recently deserted village of Ridol; and from the branch of a high tree before us a human arm, hacked out by the shoulder-blade dangled in the breeze, and at no great distance further were recently gibbeted human heads and limbs.

A state of war, we found, existed between, on the one hand, the villagers of Ridol burnt out by the Kaleobar people, leagued with Waitidal on the north-western corner, which had taken them in, and with Ritabel, our village; and on the other hand, those of Kaleobar, one of the largest villages on the island situated on the north-eastern corner, which was leagued with Kelaan and with Lamdesar, two other villages on the south-eastern coast ... Frequent raids had been made recently by these villages on Ritabel, the wife of whose chief had recently been picked off from the outside of the palisade by a lurking Kaleobar marksman, while many of the villagers showed us their recent wounds received in an attack made a few weeks before our arrival. (Forbes 1885:304) 
A decade later the warfare between the villages on Larat seemed not to have lessened. Jacobsen (1896:209) did not see himself but reported from one Captain Langen that the village of Ridol had once again been laid to waste.

The resident of Ambon, De Vries, describes the villages of the Tanimbar as having 'a fortress-like appearance' still at the beginning of the twentieth century. He presents a detailed description of the fortifications around the village of Lermatangkort:

It is built on a high rock plateau, with sharp drops on all sides. From the sea side in particular it is unscaleable, so a tall wooden staircase or ladder consisting of several sections is installed. In wartime these sections are hauled up, completely severing the link with the outside world. The ladder leads to a gate which provides access to the village. The gate is set in a wall of stacked stones, surmounted by a fence of thick, upright bamboo carved at the top into sharp spikes. Cross-beams reinforce the whole structure. The gate itself is so narrow that only one person can pass through at a time. Opposite it on the landward side is a second gate, also with a ladder. These two gates are the only ways into the village. (De Vries 1900:494)

Shortly after this, the traditional pattern of village fortification declined. The Catholic priest Drabbe (1940) describes the walls and the wars that necessitated them as a thing of the past:

The gate gives access to the village which is enclosed within a wall about $2 \mathrm{~m}$ high. The wall consists of stacked reef stones. Its remains can still be seen in many places. There are no more complete walls, because, when the Government abolished warfare, the order was given to demolish them ... In the past they served to keep enemies outside, and pigs inside. (Drabbe 1940:48)

We see this dramatic decline in fortification comparing images of the village of Omtufu. Drabbe took a photograph of the village when he was stationed in Tanimbar from 1915 (Figure 10.4). We see the old stone wall is reduced to low rubble and without gates. The same village photographed in 1903 shows bamboo palisaded gates with guards standing off to the left (Figure 10.5). In the time of high alert that Forbes observed due to the ongoing war, the gates of Ritabel were similarly palisaded and surrounded by bamboo caltrops:

All round the village we found a high strong palisade, with a portion removable, however, on the shore side in the daytime. In attempting to pass out by the landward gateway we were at once restrained by several of the villagers following us, who pointed to the ground in an excited manner, demonstrating to us its surface everywhere set with sharpened bamboo spikes, except along a narrow footpath. Their gestures instantly opened our eyes, with an unpleasant shock, to the truth that we were environed by enemies, and the village was standing on its defence. (Forbes 1885:303)

Still Drabbe (1940) was able to record beliefs and rituals to do with the protective stone walls before their falling into disuse. As in Kei, the stone walls of the village were regarded by the Tanimbarese as living entities that needed to be provisioned:

After the construction of such a village wall a sacrificial feast was also held, involving a communal meal for the whole kampong together with offerings of food first to the wall, then to the village itself, and finally to God. Before everyone began to eat (a large meal of rice with pork), the head of the village founder's lineage group took a portion of rice with a strip of pork fat, babi dolas, on top, and placed it on the wall on the seaward side of the village, speaking the words: 'Wall, we have finished stacking you up, do not let your weight press upon us'. Then a portion was placed on the ground in the village, on the seaward side of the dancing and gathering place, and the village sacrificer said to God: 'Friend (the term by which sacrificers and village criers address the Supreme Being), we have fed the wall and the village, keep the weight of the stone from us'. Thereupon the whole community repeated the prayer of the sacrificer. (Drabbe 1940:49) 


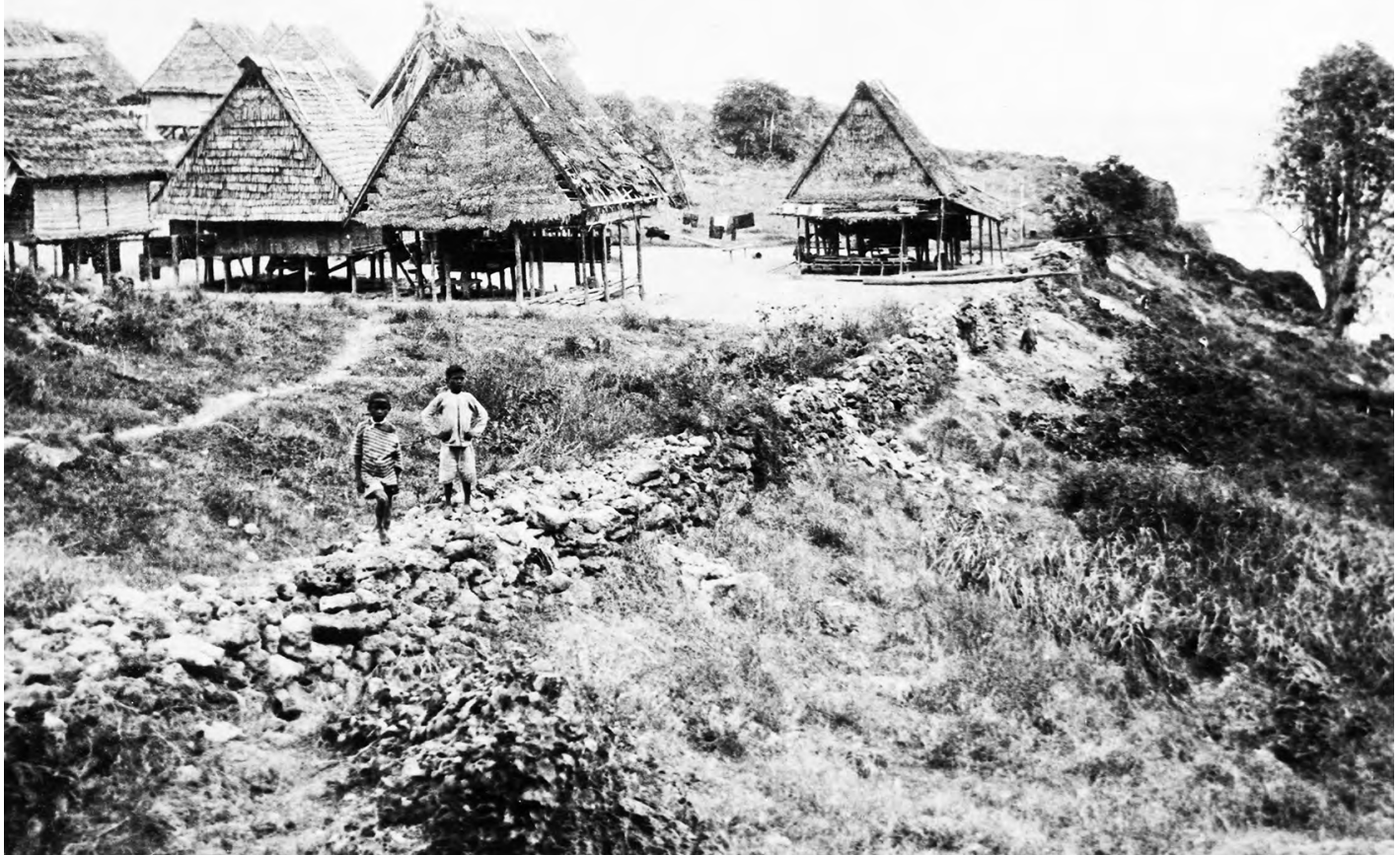

Figure 10.4. Remains of the stone wall around Omtufu village, Yamdena, Tanimbar Islands c. 1920. Source: Petrus Drabbe @ KITLV 404606.

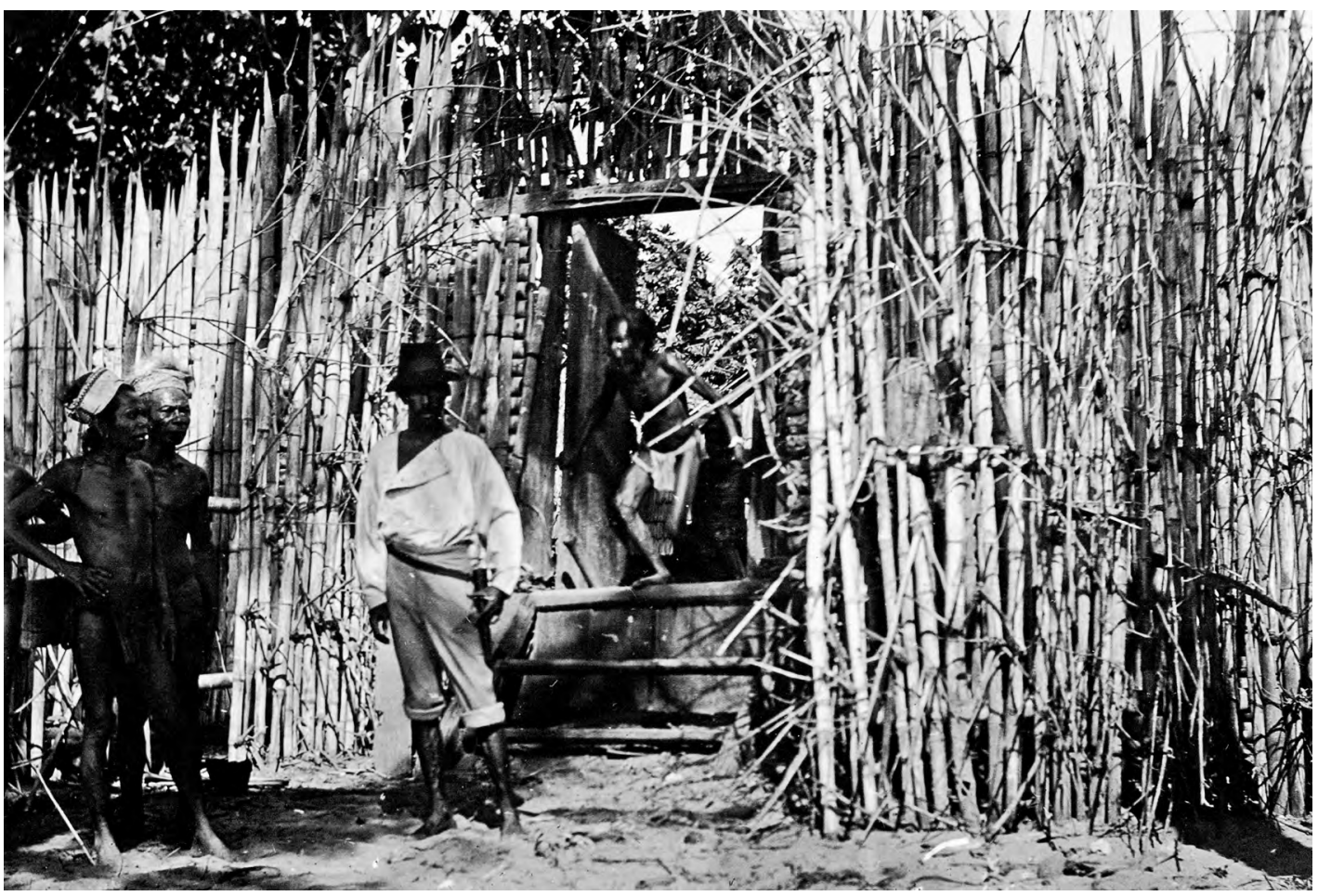

Figure 10.5. One of the entry gates to Omtufu village, Yamdena, Tanimbar Islands c. 1903, shown in use with palisading of sharpened stakes and two guards standing off to the gate's left. Source: () KITLV 82675. 


\section{Babar Islands}

Like their larger and better described neighbours, the Babar islands are known to have been home to villages fortified with stone walls. As always, Riedel provides a clear statement on the extent and type of fortification around villages (my bolding):

Most villages [on Babar itself] (let or lehol) are set on high ground above the sea, surrounded by a stone wall (lutur) two to three meters high, up to two meters wide. (Riedel 1886:342)

The most detailed description of the fortifications on the Babar islands that we have comes from after the time that they were in use (see van Dijk and de Jonge 1987; Kealy et al. 2018). The anthropologist van Dijk describes the protective lutur that traditionally surrounded villages on Marsela, the southernmost island of the Babar group, on the basis of oral traditions:

In elevated places, we still see the remains of early Marselan villages which were inhabited by various em until the beginning of the twentieth century. A village (lek or run) was really a kind of fort designed to fend off an enemy. The people lived under constant threat of war. Remains of the ring-wall which surrounded the village are still present, often with shooting holes still visible. According to informants, this wall, [whose personal name was] Wawyelya, was at least four meters high and one to one and a half meters thick. Bamboo stakes were fixed on top of the wall to make it even more difficult for an enemy to enter the village ... A gate, worrey, was equipped with large wooden doors that gave access to the village. (van Dijk 2000:159)

Van Dijk (2000:171) also describes the significance of the village walls. As in the Kei Islands, the walls were conceived as a cloth wrapped protectively around the villagers. If denuded, life would flow away from the village.

A contemporaneous account of the stone walls around villages in Babar comes from a Dutch military expedition to subdue unruly villages on Babar in 1907, which found villages heavily armed against attack. The anonymous author of a report published in the popular contemporary magazine Eigen Haard writes of the great surprise they experienced encountering walls that were 'built of stone $2 \mathrm{~m}$ high and topped with a $2 \mathrm{~m}$ high bamboo fence with stakes in between' (1907:795). The force was also warned by the local Dutch official that booby traps of caltrops and pitfalls lay all around stone walls (Eigen Haard 1907:794). In the villages of Babar they encountered a large number of guns, with each village yielding up dozens of rifles. The authorities saw these as unnecessary, given the absence of large dangerous animals in the islands, and confiscated them. Pacification was further imposed by giving troublesome villages a few weeks to move out of their inaccessible walled villages and move to the coast, where they would not be tempted to resist the rule of the 'company', as the locals still called at the time. The 1907 expedition also captured the difficult access to villages due to the steep ascents which led up to the walled villages (Figure 10.6).

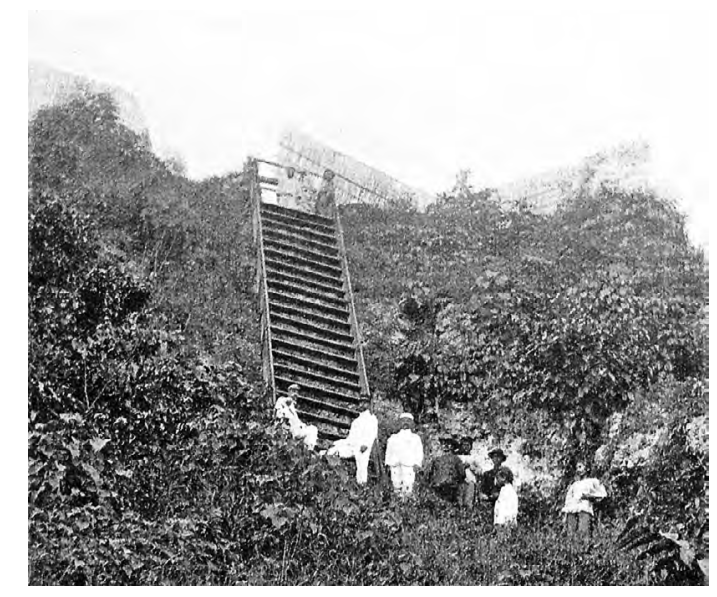

Figure 10.6. The landward gate of Wakpapapi, Babar, Babar Islands, with a steep ladder leading up to the palisaded stone wall.

Source: Eigen Haard 1907:797. 


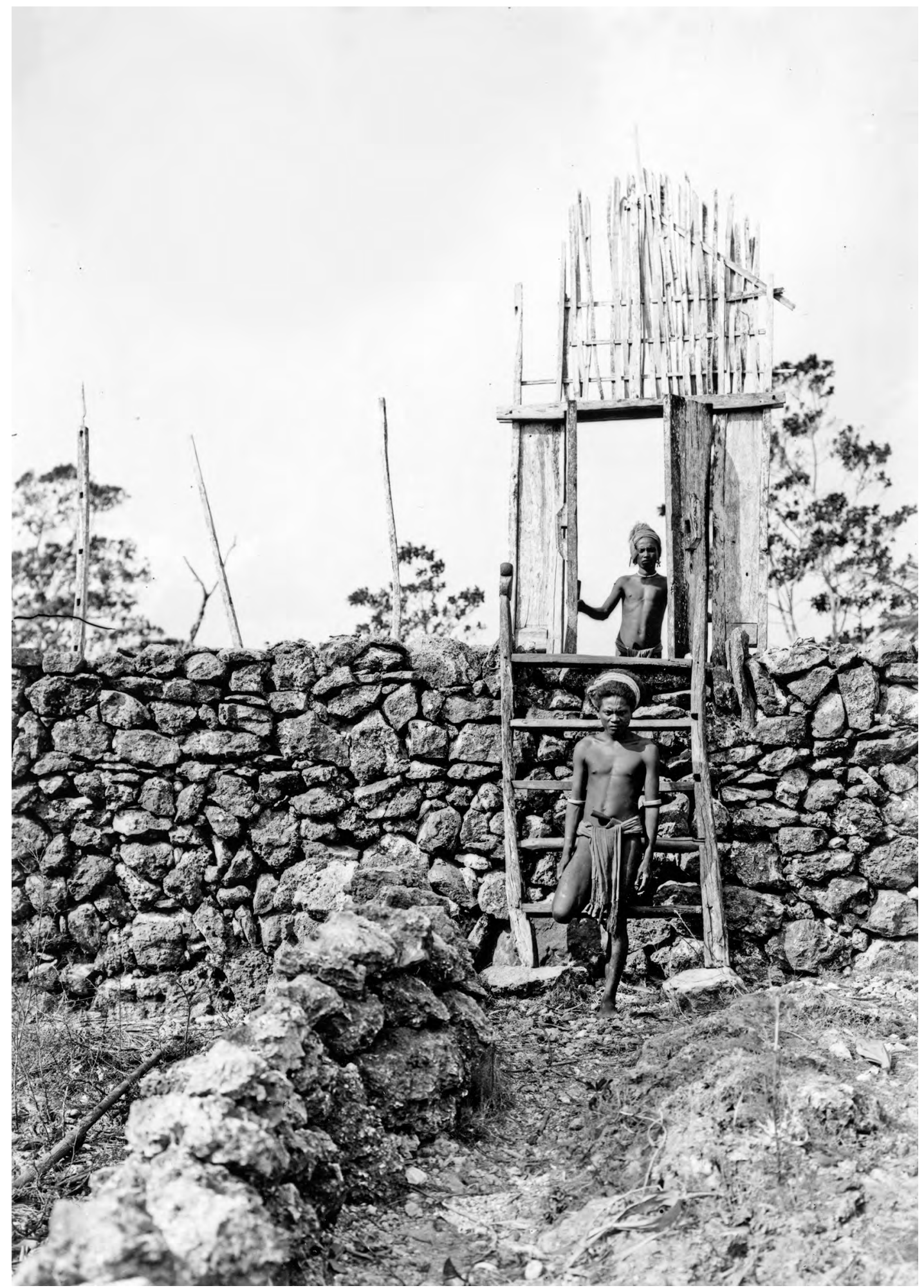

Figure 10.7. Gate over the stone wall of Lawawang village, Marsela, Babar Islands. Source: Wilhelm Müller-Wismar 1913 @ Museum für Völkerkunde Hamburg. 


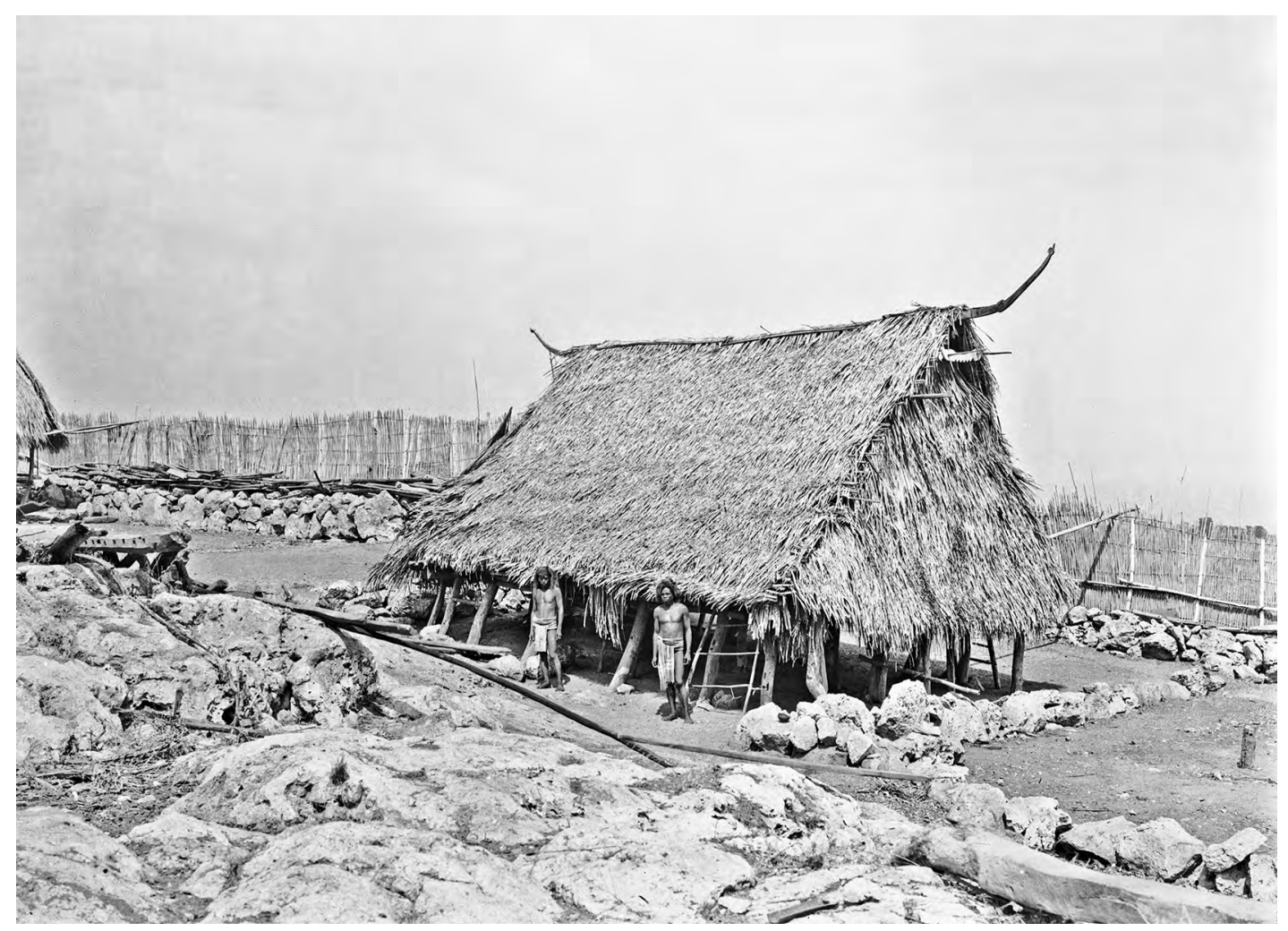

Figure 10.8. Stone wall palisaded with bamboo around Latalola village, Marsela, Babar Islands.

Source: Wilhelm Müller-Wismar 1913 @ c Museum für Völkerkunde Hamburg.

The German linguist and ethnographer, Wilhelm Müller-Wismar, visited the islands in 1913 and took multiple photos, taking in the fortifications around villages, particularly on the island of Marsela, that show striking similarities with those described for other parts of southern Maluku. Figure 10.7 shows a man-height wall built up with stones; the wall is topped with a gate with wooden doors led up to by steep steps; stakes are embedded in the top of the walls, presumably used for attaching palisading in times of war. Figure 10.8 shows another village surrounded by a stone wall topped with an extensive bamboo palisade and reinforced with piles of logs stacked on the wall. These images show that, although pacification had begun at least in 1907 on Babar Island itself, the traditional fortified village pattern persisted beyond that for some time still.

\section{Leti and Luang island groups}

Located in the southeastern corner of southern Maluku, directly adjacent to Tutuala on the eastern tip of Timor, the islands of Leti, Moa, Lakor, Luang and Sermata are also recorded as having their traditional villages fortified. Riedel describes the walls as imposing structures of considerable height and thickness with similar palisades and gates as found in other island groups:

Most villages are located on isolated knolls or outcrops of coral stone, 20 to $50 \mathrm{~m}$ above sea level, and surrounded by a stone wall, lutru, three meters tall and one meter thick with two to four entrances or gates, which are closed in times of danger. (Riedel 1886:379)

Around each village on [on Luang and Sermata] there is a stone wall, lutru, $2.25 \mathrm{~m}$ in height and $2 \mathrm{~m}$ thick. Entry is via two gates, one at the front and one at the rear. The majority of villages are located close to the sea but at some elevation, and where possible in the vicinity of a water source. In the past, bamboo fortifications and caltrops, hoora, were placed around them in time of war. (Riedel 1886:317-318) 


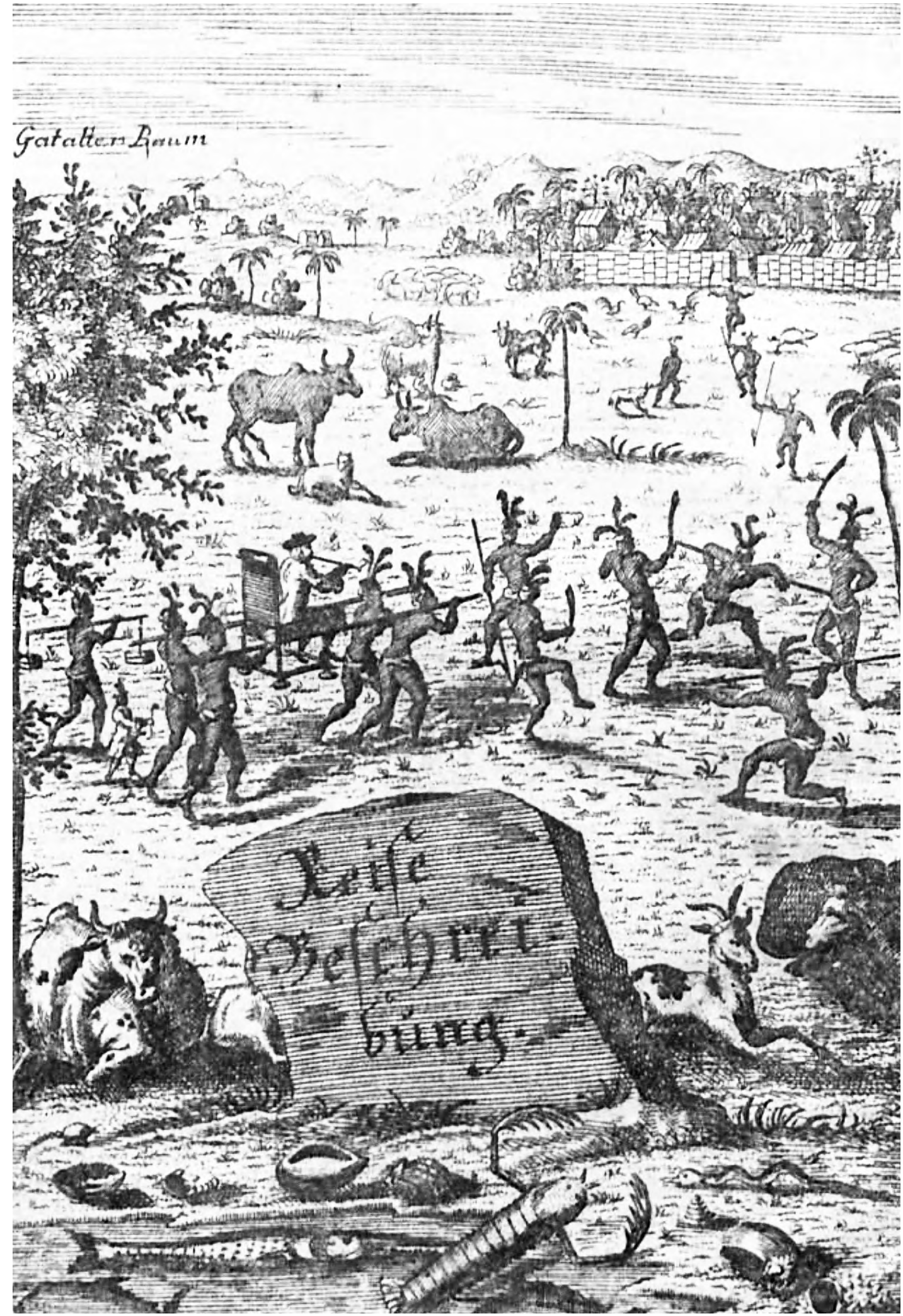

Figure 10.9. A Letinese walled village in the top right-hand corner of the frontispiece of Barchewitz (1751).

Source: Barchewitz 1751 
It is for islands in this group that we have the earliest account of village fortification. Ernst Christoph Barchewitz was a German in the service of the Dutch East India Company (Vereenigde Oostindische Compagnie, or VOC) stationed on the island of Leti between 1714 and 1720 . His travelogue of 1751 provides the first depiction of a stone wall surrounding a village in southern Maluku (Figure 10.9). In his 1730 work he describes the walls as ubiquitous due to the perpetual state of war between villages:

Directly to the east ... surrounded by a strong wall, was the village of Leyduttun. All the villages of Leti had such walls for their protection, because the local rulers were always at war with one another. These walls were made of large flat stones, and provided with holes for shooting. Neither chalk nor lime was used in their construction, the dry stones simply being placed on top of one another. (Barchewitz 1730:212-213)

Fortification continued to be a prominent feature of Leti and Moa in the nineteenth century, with Bosscher (1854:436) remarking that the villages 'could almost be called small forts, untakable for an indigenous enemy'. Still in the early twentieth century De Vries (1900) remarked on the strange walled villages of Leti, similar to those on Tanimbar:

Toetoekai and Lehoelele are the strangest villages one can imagine. Here are the same fortresses that I had already seen on Tanimbar, but now with the difference that having entered through the gate, one sees nothing but walls! The only access to the village, which is perched up on a rock plateau, is by a staircase leading to the gate. This gate is so narrow that the sedan chair in which I was sitting, an ordinary armchair, could pass through only with difficulty. There are two such gates in the stone wall that surrounds the whole stronghold.

Having squeezed through this entrance, one sees a street ahead, lined on both sides by high walls over which, upon my arrival, the heads of curious inhabitants fleetingly appeared, only to duck away again fearfully.

Behind those walls are the parts of the village which are separated again by stone barriers; and in order to be extra safe, everyone is also protected in the same way. (De Vries 1900:600)

Despite the fact that it appears to have had enormous regional influence (Pannell 2007), there is very little ethnographic or historical documentation of the Luang island group. No descriptions of traditional walled villages on the islands beyond that in Riedel (1886) have been located. Pannell (2007:91) notes the remains of traditional villages are still evident today as a series of multi-terraced, stone-walled compounds on hilltops. Müller-Wismar photographed one of these villages (Figure 10.10), but it is not known whether it was still inhabited at the time.

\section{Kisar and the northern arc of Barat Daya Islands}

Kisar and the northern arc of Barat Daya Islands (Roma, Damar, Teun, Nila and Serua) form a loose island chain southwest of the area under discussion. Perhaps with the exception of Kisar, they were out-of-the-way places that have altogether less relevant historical documentation than the other places discussed thus far. Nonetheless, here too we find clear, albeit limited, descriptions of fortified villages. 


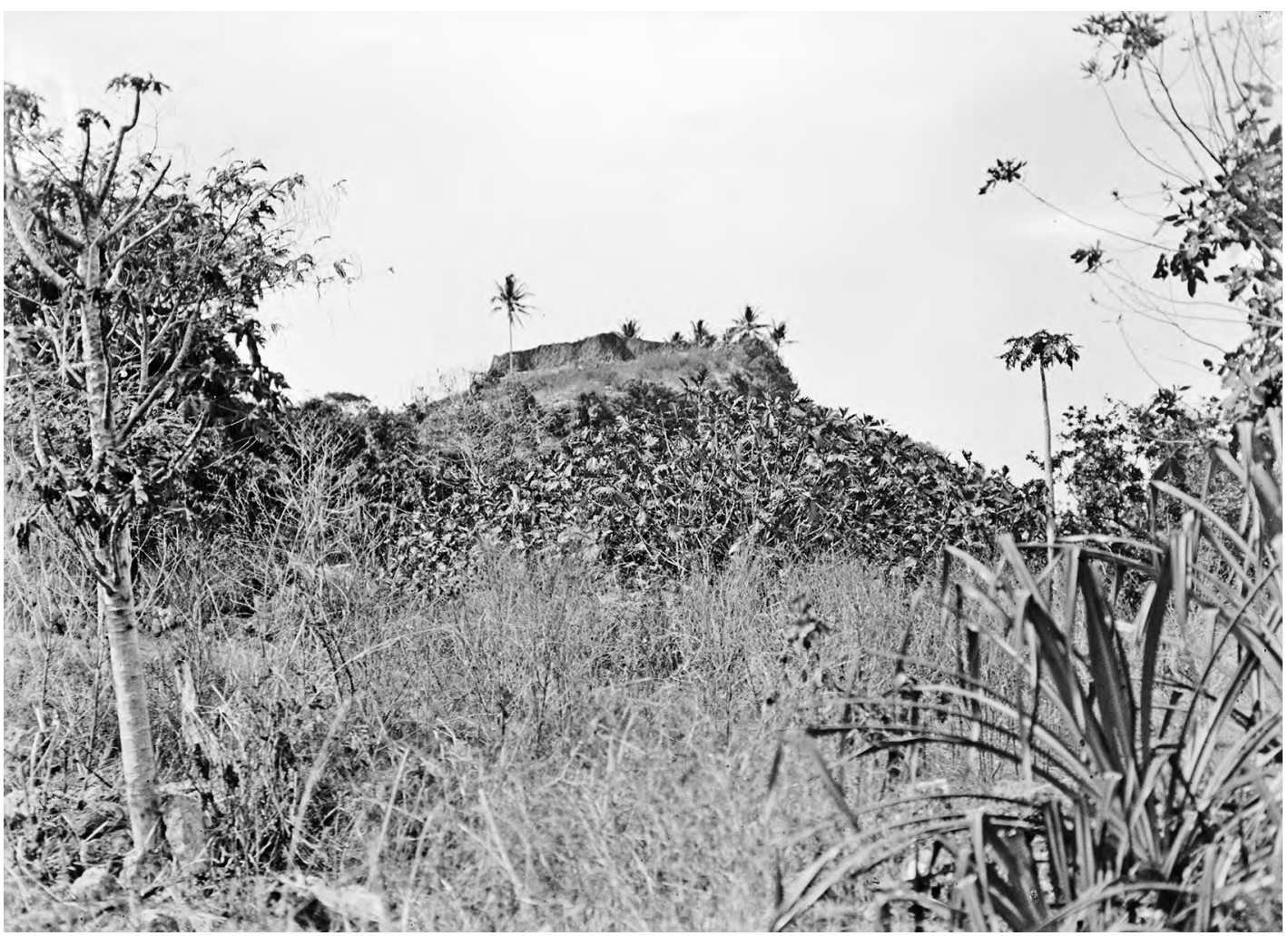

Figure 10.10. Hilltop fortified village on Luang Island.

Source: Wilhelm Müller-Wismar 1913 @ Museum für Völkerkunde Hamburg.

As always, Riedel (1886) is helpful, explicitly stating, even for the remote Roma, Teun, Nila and Serua islands, that villages were fortified with stone walls. For the islands of Kisar and Damar, he provides more information including the local names of the walls (my bolding):

The villages (lete) on Damar are built on the tops of hills, ringed with stone walls, lutur, and governed by orlete or chiefs and headmen. These chiefs have little influence, however; the heads of the individual houses or families do not permit meddling in their private disputes, which can lead to war. (Riedel 1886:463)

The old villages [on Kisar], in so far as they have not been destroyed, are ringed by stone walls $5 \mathrm{~m}$ in height and $2 \mathrm{~m}$ thick. These villages have thirty or more houses and are called heruke lalaape 'big villages', as distinct from the heruke tataane or temporary forts located on flat lands. (Riedel 1886:422)

While Riedel suggests that fortified villages were in decline on nineteenth-century Kisar, they nonetheless remained prominent in the landscape. Jacobsen (1896:118) notes that some hilltop villages still had walls at the end of the nineteenth century. In 1891, when Bassett-Smith visited Damar, the traditional pattern of village fortification was still practised, with each village being 'enclosed by dry-stone wall, having a wooden ladder for means of entrance and exit' (BassettSmith 1894:136). The Siboga zoological and hydrological expedition of 1899-1901 through eastern Indonesia photographed these stone walls around some villages on Damar (Figure 10.11). Pannell (1991) observed the remains of stone walls (lutruni) surrounding old villages on Damar but makes no mention of any particular cultural significance they may have had. 


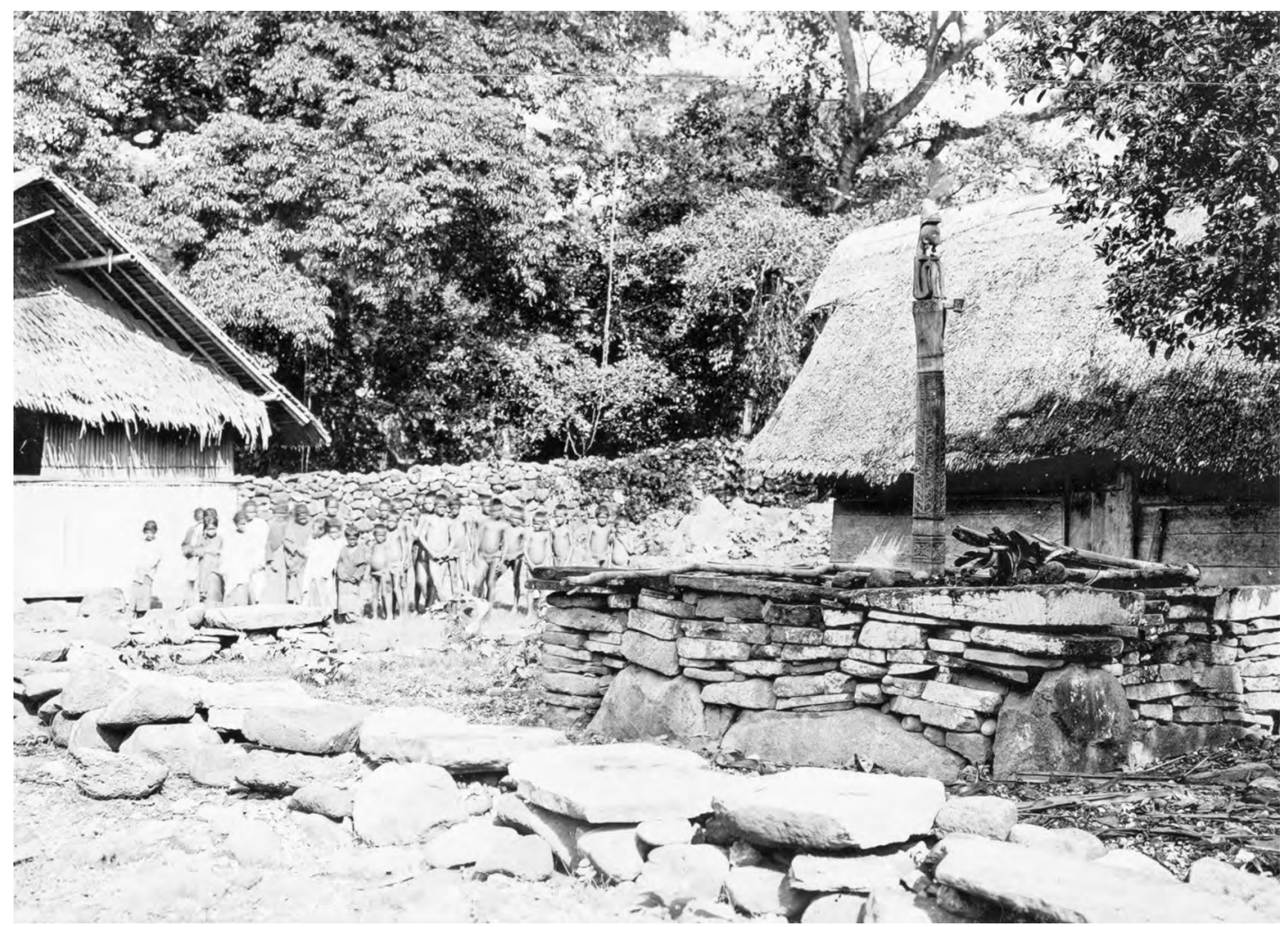

Figure 10.11. Wulur village on Damar island enclosed by a stone wall visible behind villagers.

Source: Siboga Expedition 1900 (c) University of Amsterdam Library.

\section{The southern Maluku village fortification pattern}

In the descriptions and depictions in the previous sections, a common pattern of traditional fortified settlement across southern Maluku has emerged: villages on hilltop and/or cliff-edge locations encircled by high stone walls with narrow gated entrances, often hidden and only accessible by steep ladders or stairwells that could be dismantled, barricaded and/or booby trapped in times of danger. Across the region, these protective stone walls were made of rough blocks of coral stacked to several metres, often extended in height by bamboo palisades and spotted with holes through which approaching enemies could be shot at. Within villages, numerous smaller walls were frequently present to prevent an invading enemy from storming the village too easily. The villages fortified by these stone walls existed within the context of a highly fragmented political landscape in which the many small polities were in a state of near perpetual warfare with one another. The protecting stone walls occupied an important place in society, offering substantial protection against indigenous forces. They were widely treated by villagers as living entities, provisioned with food and clothing.

The sources we have looked at make clear that fortified villages existed already in the early eighteenth century in some parts of southern Maluku and persisted until Dutch pacification in the early twentieth century. This begin date aligns well with the available radiocarbon dates in eastern Timor, that suggest the widespread emergence of fortified settlements there occurred after the sixteenth century and into the seventeenth century (O'Connor et al. 2012:208-211). The coinciding timing suggests that village fortification in southern Maluku and eastern Timor were part of single historical movement, a point that is reinforced by the linguistic data in the following section. 


\section{A linguistic view on stone wall-building}

The common pattern of village fortification found across southern Maluku is also reflected in language. In many of the descriptions presented in the previous section the reader will have observed the term lutur or similar, used for this protective stone wall. In this section, I apply historical linguistic methodology to throw light on the history of the term \#lutuR and, in turn, on the history of the stone building. ${ }^{5}$ I show that the evidence from language points to stone wall-building as having diffused across southern Maluku, including far eastern Timor.

One of the central tasks of historical linguistics is to determine the relatedness of languages and group them into families and subgroups of more closely related languages within those families. This is achieved through the application of the blandly named 'comparative method', a set of procedures in which a feature-by-feature comparison of two or more languages with common descent from a shared ancestor is made in order to extrapolate back and hence infer the properties of that ancestor. The principal (but not only) feature comparison that is made across languages to establish relationships is between phonemes, the minimally distinctive sounds of a language. Over time, words change in how they are pronounced. These changes do not typically occur to individual words in isolation; rather, the same sound (often under definable phonetic conditions) tends to change in a regular way across the entire vocabulary of a language. This is known as the principle of regularity of sound change. Languages that show a high degree of regular sound correspondences across numerous form-meaning pairings (words or morphemes with similar meanings) can be deemed related to one another.

Establishing the sound correspondences between related languages makes it possible to uncover further aspects of linguistic history in two ways that are relevant to us here. First, related languages that share sets of sound changes that are not present in other members of the family can be said to form a subgroup, a set of languages that share a common (low-level) ancestor. Knowing the subgroups of a language family and plotting them against geography helps us track the paths of migration and dispersal which populations of speakers have followed in the past. Second, the regularity of sound change also allows us to distinguish words with a common heritage from those that are borrowed. Where two related languages have words of similar meaning that can be related to each other by regular sound changes, that word is regarded as inherited from the common ancestor. Where two related languages have words of similar meaning with only irregular sound correspondences, it indicates that borrowing is likely involved.

The known instances of the term \#lutuR are plotted in Figure 10.12..$^{6}$ These can be clearly divided into regional blocks on the basis of differences in semantics. In the western half of Timor and the islands to its north, members of the \#lutuR set are verbs meaning to pile or stack up stones. In central Timor, members of the \#lutuR set are nouns typically glossed as 'fence', but the items appear to denote any kind of man-made barrier demarcating portions of land. In the east of Seram, one language, Seram-Laut, has lutur for 'stone or coral fish trap' (Ellen 2003:163). Finally, across a dozen languages in southern Maluku we find members of the \#lutuR set denoting walls made of piled-up stones, in some cases, specifically or especially, those around villages.

\footnotetext{
5 In this section, the symbol \# marks a word that is not a reconstruction, but rather a generalisation across forms in an etyma set. The symbol * is reserved for words that are truly reconstructable to a protolanguage on the basis of the comparative method.

6 In compiling this data, I looked through sources and dictionaries from the region. This included many languages from the Nusa Tenggara Timur area that ultimately did not evidence a \#lutuR word, e.g. Pampus (1999) on Lamaholot in the Solor archipelago, Onvlee et al. (1984) on Kambera on Sumba.
} 


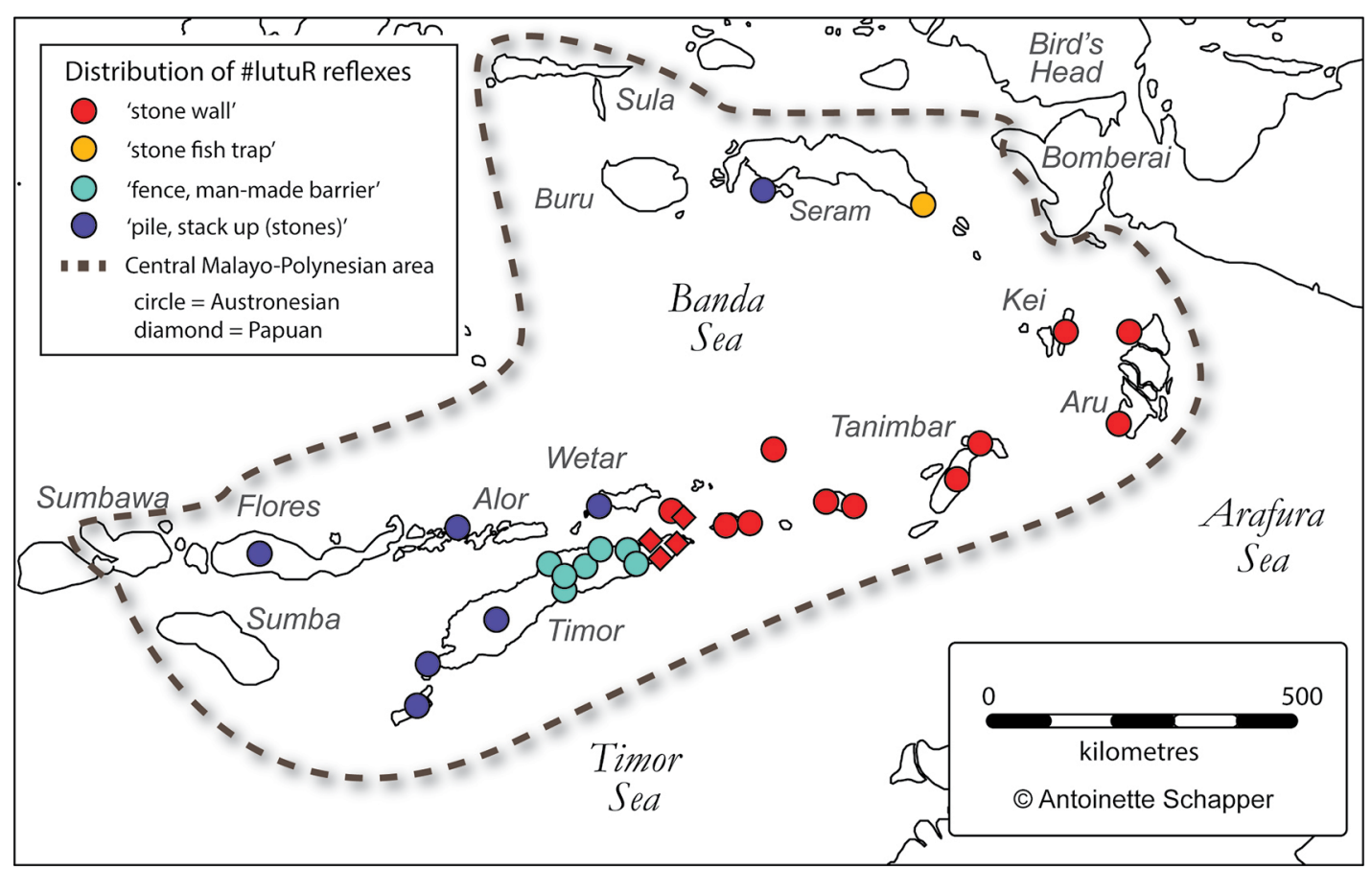

Figure 10.12. Distribution of \#lutuR in Southeastern Wallacea.

Source: Antoinette Schapper.

With this last meaning, \#lutuR is found is two unrelated families: Austronesian languages, a large family extending from Taiwan in the north to Madagascar in the west and Hawai' $i$ and Easter Island in the east (Blust 2009), and the eastern members of Papuan languages belonging to the Timor-Alor-Pantar family, which is limited to southeast Wallacea (Schapper et al. 2014). Given that these families have no relationship with one another other than areal, this points to \#lutuR having been borrowed from members of one family by the other. The direction of borrowing here is almost without doubt from the Austronesian languages into the Papuan languages. Instances of \#lutuR are not found in the related Papuan languages of central Timor or Alor-Pantar, but rather are limited to those of eastern Timor and Kisar, adjacent to Austronesian languages evidencing \#lutuR with the same sense (a point returned to below). To demonstrate that the term goes back to the common ancestor of the Papuan languages, we would need to find an instance of \#lutuR in one of these other languages which form distinct primary subgroups of the family (Schapper 2017). The eastern Timor Papuan groups are, moreover, known to have adopted many cultural categories and associated vocabulary items from Austronesian society (McWilliam 2007).

Table 10.1. Proto-Malayo-Polynesian reconstructions around walls and their building.

\begin{tabular}{|l|l|}
\hline "pager & 'enclosure; palisade around a village; fence around a planted tree or cultivated field' \\
\hline "qalad & 'fence, wall' \\
\hline "qatur & 'pave with stones; pile or stack up, arrange, order, put in sequence' \\
\hline "susun & 'stack up, pile in layers' \\
\hline
\end{tabular}

Source: Blust ACD. 
Table 10.2. Austronesian languages with \#lutuR 'stack, pile up stones'.

\begin{tabular}{|l|l|l|}
\hline Language & Form & Meaning \\
\hline Asilulu & lutu & 'to arrange (stones) one on top of the other' (Collins 2003:61) \\
\hline Ili'uun & lutu(r) & 'pile up' (Josselin de Jong 1947:125) \\
\hline UabMeto & lutumbatu & 'steenen opstapelen' (Middelkoop n.d.) \\
\hline Termanu & lutubatu & $\begin{array}{l}\text { 'steenen opstapelen, vooral onder een boom om er eene rustplaats van te maken; } \\
\text { de opgestapelde hoop steenen' (Jonker 1908:335) }\end{array}$ \\
\hline Helong & lutan & 'opstapelen' (Jonker 1908:335) \\
\hline Kedang & lutur & 'heap, pile, stack up, pile stones on [something]' (Samely and Barnes 2013:383) \\
\hline Manggarai & katur & 'menjusun batu2; susunan batu' < k-lutar 'pagar batu, susunan batu' Verheijen $(1967: 196,254)$ \\
\hline
\end{tabular}

Source: See references throughout table.

Table 10.3. Austronesian languages with \#lutuR 'fence, man-made barrier'.

\begin{tabular}{|l|l|l|}
\hline Language & Form & Meaning \\
\hline Tetun & lutu & 'hedge, fence, enclosure, circular mud wall' (Morris 1984:135) \\
\hline Tokodede & luto & 'fence' Capell (1944:332-333) \\
\hline Kemak & lutu & 'fence' Capell (1944:332-333) \\
\hline Mambae & luto & 'fence' Capell (1944:332-333) \\
\hline Dadu'a & lutu & 'sebe, cerca viva,pagar' (Penn 2006:98) \\
\hline Waima'a & l'utu & 'fence' (Belo et al. n.d.) \\
\hline Naueti & 'lutu & 'fence' (Veloso 2016:135) \\
\hline
\end{tabular}

Source: See references throughout table.

Table 10.4. Austronesian languages with \#lutuR 'stone wall'.

\begin{tabular}{|c|c|c|}
\hline Language & Form & Meaning \\
\hline Kei & lutur & 'muur, e.g. entutlutur een muur stapelen' (Geurtjens 1921b:103) \\
\hline \multirow[t]{2}{*}{ Ujir } & lutur & 'susunan batu, benteng tradisional' (Handoko 2016:170) \\
\hline & luti & to pile up stones, stone wall (Emilie T.B. Wellfelt pers. comm.) \\
\hline West Tarangan & lutur & (archaic) stone fence, wall, to cover with stones (Rick Nivens pers. comm.) \\
\hline Fordata & lutur & 'gestapelde muur' (Drabbe 1932a:69) \\
\hline Yamdena & lutur & 'muur van opgestapelde steenen' (Drabbe 1932b:65) \\
\hline Babar & lutur & 'steenen muur ... van twee tot drie meter hoog, tot twee meter breed' (Riedel 1886) \\
\hline \multirow[t]{2}{*}{ Central Marsela } & lutur & stone wall around a village (Toos van Dijk pers. comm.) \\
\hline & lukra & stone wall around the garden (Toos van Dijk pers. comm.) \\
\hline \multirow[t]{2}{*}{ Damar } & lutur & 'steenen ringmuur' (Riedel 1886) \\
\hline & lutruni & 'village wall' (Pannell 1991:80) \\
\hline Wetan & lutri & 'wall, especially the stone or coral wall round the village' (Josselin de Jong 1987:229) \\
\hline Luang & lutru & 'steenen muur ... van 2.25 m hoogte en 2 m dikte' (Riedel 1886) \\
\hline Leti & lutur lutru & $\begin{array}{l}\text { stonewall (Aone van Engelenhoven pers. comm.); 'muur van de negorij, benteng' } \\
\text { (Jonker 1932:144) }\end{array}$ \\
\hline Kisar & lukur & $\begin{array}{l}\text { stone wall, including protective village walls and field garden boundaries } \\
\text { (John Christiansen pers. comm.) }\end{array}$ \\
\hline
\end{tabular}

Source: See references throughout table. 
Table 10.5. Papuan languages with \#lutuR 'stone wall'.

\begin{tabular}{|l|l|l|}
\hline Language & Form & Meaning \\
\hline Fataluku & lutur(u) & $\begin{array}{l}\text { any kind of construction involving the stacking of stones, including village and garden } \\
\text { walls, dance places and graves (Aone van Englenhoven pers. comm.) }\end{array}$ \\
\hline Oirata & lutur(e) & 'village wall' (Josselin de Jong 1937:253) \\
\hline Makalero & lutur & stone wall, including village walls and garden walls (Juliette Huber pers. comm.) \\
\hline Makasae & lutur & stone wall (Juliette Huber pers. comm.) \\
\hline
\end{tabular}

Source: See references throughout table.

Yet, because \#lutuR is not found outside of southeast Wallacea, we cannot account for it simply as a run-of-the-mill borrowing of an Austronesian etymon into Papuan languages. All the Austronesian languages outside of Taiwan share a common ancestor known as Proto-MalayoPolynesian (PMP). There is a significant body of work on the history of Malayo-Polynesian languages, and an extensive vocabulary has been reconstructed for PMP. In the domain of wall-building, Table 10.1 gives the relevant reconstructions of PMP lexical items. Noticeably absent from this list is \#lutuR, whose reflexes are set out in Tables 10.2, 10.3 and 10.4 according to semantics. There are two possibilities to account for the regional distribution of \#lutuR in Austronesian languages: inheritance or diffusion. ${ }^{7}$

Inheritance would mean that this lexeme was innovated in a common ancestor to all the languages. Austronesian languages in this area have been claimed to all belong to the CentralMalayo-Polynesian (CMP) subgroup (Blust 1982/3, 1993) and the term could be traced back to Proto-Central-Malayo-Polynesian (PCMP). The CMP subgroup putatively takes in all Austronesian languages in the Minor Sundic Island Chain east of Bima spoken on the eastern half of Sumbawa, together with all of the islands of central and southern Maluku. Members of the \#lutuR set are, however, not in evidence across the whole proposed CMP area. Rather they are limited to the southern arc of islands. And within this arc, languages reflecting \#lutuR belong to a range of different primary subgroups of CMP that are not thought to be related to one another below PCMP.

The clustering of the different senses of \#lutuR into geographic areas rather than according to subgroups further suggests areal diffusion is a significant factor for understanding the distribution of \#lutuR. For example, the central Timor languages (i.e. Tokodede, Kemak and Mambae), which according to Hull (1998) form the 'Ramelaic' subgroup distinct from the other Austronesian languages of Timor, nevertheless use \#lutuR in the same way as their nearest 'extraRamelaic' neighbours in the eastern half of Timor (e.g. Galoli, Waima'a, Naueti), that is, in the sense of 'fence, man-made barrier'. The areality rather than genealogy of these different semantic clusterings is also seen across familial boundaries. In Table 10.5 we see that the semantics of \#lutuR terms in the eastern Timor Papuan languages conform with those of the neighbouring Austronesian languages in the southern Maluku region where village fortification was prevalent. This likely reflects adoption of the term for stone wall-building from that area.

An examination of sound correspondences likewise indicates that \#lutuR has been borrowed across the Austronesian languages in the region often with the specific sense of a stone wall fortifying a village. Particularly telling in this respect is the appearance of doublets, two reflexes of the ultimately same ancestral word acquired through different historical routes. ${ }^{8}$ In Ujir,

7 There is a third logical possibility: chance similarity. However, this is not considered here as the combined lexical and semantic similarities of the forms in Tables $10.1,10.2$ and 10.3 are clearly beyond chance.

8 English is well known for its doublets acquired through contact with other Indo-European languages. For example, skirt and shirt are both ultimately from Proto-Germanic *skurtjōn-, the former reflecting borrowing from Old Norse skyrta and the latter inheritance from Old English scyrte. 
we find the doublet lutur meaning a stone wall fortification (Handoko 2016) and luti, which can be a noun meaning 'stone wall' or a verb 'to stack up stones' (Emilie T.B. Wellfelt pers. comm.). Word-final PMP ${ }^{*} \mathrm{R}$ is regularly reflected as / $\mathrm{i} /$, as in Ujir rengai 'hear' $<\mathrm{PMP}{ }^{*}$ deneR; the presence of a final $/ \mathrm{r} /$ therefore marks Ujir lutur as irregular and marks it out as borrowed. By contrast, luti looks to be regular, with the loss of unstressed /u/ before /i/ expected. Central Marsela has a similar doublet: lutur, denoting a protective stone wall around a village, is irregular, with PMP *t having / $\mathrm{k} /$ as its regular reflex in the language (e.g. (wo)kel 'three' <PMP *telu), and indicates that the idea of fortifying villages with a stone wall diffused from elsewhere; lukra, denoting a stone wall around the garden, by contrast, shows the expected sound change of PMP ${ }^{*} \mathrm{t}>/ \mathrm{k} /$ and may be inherited or (seeing as the final $/ \mathrm{a} /$ is unexplained) at least borrowed at an earlier stage than lutur, before the ${ }^{*} \mathrm{t}>/ \mathrm{k} /$ sound change took place. Thus, in both Ujir and Central Marsela, the word lutur shows clear signs of borrowing in the specific sense of stone wall used for fortification.

Not all languages with an instance of \#lutuR show irregular sound correspondences. However, regularity does not rule out an item from being a borrowing. Borrowings can show regular correspondences where the sounds they contain are stable, as the consonants ${ }^{*} \mathrm{l},{ }^{*} \mathrm{t}$ and, to a lesser extent, ${ }^{*} \mathrm{R}$ tend to be in Austronesian languages in the area under consideration. A pertinent example is Dempwolffs (1938) reconstruction Proto-Austronesian *kuTa 'fortress'; reflexes of this item in Austronesian languages conformed to the established sound correspondences, even though it was known to be a borrowing from Sanskrit that diffused across Island Southeast Asia as part of the Indianisation that took place from around AD 300. That some of the Austronesian reflexes of \#lutuR, particularly in the semantic set 'stone wall', show irregularities and that this form-meaning pairing is clearly borrowed into the neighbouring Papuan languages in eastern Timor indicates that the practice of building stone walls, including to fortify villages, diffused across southern Maluku.

\section{Discussion}

This paper has sought to add context, both geographical and historical, to the debate about the origins of fortified settlements in far eastern Timor. These village fortifications were part of a common pattern of traditional fortified settlement found across southern Maluku that already existed in the early eighteenth century in some parts of southern Maluku and persisted until Dutch pacification in the early twentieth century. The southern Maluku pattern of settlement fortification consisted of villages on hilltops and cliffs enclosed by stone walls with gated entrances, only accessible by steep stairs. The stone walls were made of rough blocks of coral piled up to several metres in height, often extended with bamboo palisading and surrounded by booby traps. The protecting stone walls of villages offered substantial protection against attack and were often viewed by indigenous peoples as living entities needing food and clothing.

Fortifying a village with walls of piled-up stone is not a radical technological innovation. Walled villages were found scattered about the Malay archipelago in the early modern period. What stands out in southern Maluku and far eastern Timor region is the united vocabulary which is used: \#lutuR in the sense of 'stone wall' is used across the whole of the region. Elsewhere in Maluku we find borrowings from western Indonesia are used for stone walls (e.g. Malay benteng, ultimately from Min hông sêng; Malay kota, ultimately from Sanskrit kotala). These terminologies are also found in West Timor and other parts of Nusa Tenggara Timor (e.g. Uab Meto kot 'fort' McWilliam 1996:142; Wersing kot 'defensive wall' Schapper field notes) as well as in the languages of the trading states of South Sulawesi (e.g. Makasarese benteng, kota, lodji, Cense 1979:932). Even if inspired by fortifications such as these to the west, the linguistics makes clear 
that the practice of building stone walls used in the fortification of villages spread across southern Maluku including into eastern Timor. The term \#lutuR in the sense of 'stone wall' has diffused across the boundaries of the Austronesian and Papuan language families in the region and shows, through recurrent irregularity in sound correspondences, a pattern of borrowing between the Austronesian languages.

We have no accounts of the eastern Timor fortified villages at the time of their occupation. Looking at the southern Maluku villages gives us insights into the likely functioning and significance of village fortification within eastern Timor. Realisation that the eastern Timor fortifications are part of a wider regional pattern also places a question mark on the areally restricted social factors identified by O'Connor et al. (2012) and McWilliam (Chapter 6, this volume) as possible drivers of fortification in eastern Timor. Maize was not a significant crop in most of southern Maluku and so cannot have precipitated a population boom which saw an intensification in territorial warfare there. Similarly, southern Maluku was not a source for sandalwood. The impact of the remaining two factors, a new trade in firearms and a significant increase in demand for trade in human slaves, is difficult to determine. McKinnon questions whether warfare in Tanimbar was really exacerbated by the increased weaponry of the colonial powers:

from early accounts and from accounts of contemporary Tanimbarese, one perceives that intervillage warfare was a persistent fact of life in the islands. Wars or, perhaps more properly, headhunting raids could be instigated by disputes concerning rights over land and reefs, or by disputes relating to intervillage thefts, adultery, murder or insults. (1991:7)

The historical accounts that we have seen from elsewhere in southern Maluku indicate that low-level warfare and raiding was a cultural practice, not caused specifically by resource scarcity but the normal way of life, with the smallest misdemeanours or offences occasioning violence. Schapper (2019) argues that in the seventeenth century Dutch naval aggression, in particular the massacre of the Bandanese in 1621, caused widespread fear amongst indigenous populations. This is put forth as a potential trigger for the spread in village fortification in southern Maluku, while endemic cultures of warfare meant the trend was continued once established.

This study, finally, highlights how the examination of linguistic data is an important analytical tool with which to deepen our understanding of processes of cultural diffusion. Comparing linguistic vocabularies for fortification in eastern Indonesia has shed significant light on a debate in the archaeological literature, identifying a region in which village fortification diffused widely between communities.

\section{References}

Barchewitz, E.C. 1730. Allerneueste und wahrhaffe ost-indianische Reise-Beschreibung: ... benebst e. ausführl. Land-Charte d. Sudwester-u. Bandanesischen Insulen, welche in anderen Land-Charten nicht gefunden, noch in denen Geographien beschrieben werden. J. Christoph and J.D. Stößeln, Chemnitz.

Barchewitz, E.C. 1751. Der Edlen Ost-Indianischen Compagnie der vereinigten Niederlande gewesenen commandirenden Officiers auf der Insul Lethy, Neu-vermehrte Ost-Indianische Reise-Beschreibung: Darinnen I. Seine durch Teutsch-und Holland nach Jndiengethane Reise; II. Sein eilff-jähriger Aufenthalt auf Java, Banda und den Südwester-Insuln, Glücks- und Unglücks-Fälle, seltsame Begebenheiten, auch remarquirte rare Gewächse, Bäume, Früchte, Thiere, Fische, Insecten, Berge, Vestungen, Nationen, Gewohnheiten, Aberglauben der Wilden, und viele andere Denckwürdigkeiten mehr; III. Seine RückReise, der dabey erlittene grausame Sturm, und endlich glücklich erfolgte Ankunft in sein Vaterland, umständliche erzählet wird; Nebst einem vollständigen Register. Johann David Jungnicol, Erfurt.

Bassett-Smith, P.W. 1894. Damma Island and its natives. Journal of the Anthropological Institute of Great Britain and Ireland 23:134-141. doi.org/10.2307/2842448. 
Bataviaasch Genootschap van Kunsten en Wetenschappen 1874. Tractaat van vreedetusschen de Edele Oost-Indische Compagnie de negorijen van Oedjier en Gabel. Notulen van de Algemeene en BestuursVergaderingen van het Bataviaasch Genootschap van Kunsten en Wetenschappen 11:149-151.

Belo, M. da C.A., J. Bowden, J. Hajek, N.P. Himmelmann and A.V. Tilman n.d. Glosáriu Waima’a Caisido. Department of Linguistics, Ruhr-University, Bochum.

Blust, R. 1982/3. More on the position of the languages of Eastern Indonesia. Oceanic Linguistics 22/23(1/2):1-28.

Blust, R. 1993. Central and central-eastern Malayo-Polynesian. Oceanic Linguistics 32(2):241-293. doi.org/10.2307/3623195.

Blust, R. 2009. The Austronesian languages. Pacific Linguistics. The Australian National University, Canberra.

Bosscher, C. 1854. Statistieke schets der Zuidwester-eilanden. Tijdschrift van het Bataviaasch Genootschap 2:419-458.

Brumund, J.F.G. 1845. Aanteekeningen gehouden op eene reis in het oostelijke gedeelte van den indischen archipel. Tijdschrift voor Nederlandsch-Indië 15:39-89, 251-299.

Capell, A. 1944. Peoples and languages of Timor. Oceania 14(4):311-337. doi.org/10.1002/j.18344461.1944.tb00406.x.

Cense, A.A. 1979. Makasaars-Nederlands woordenboek [Makassarese-Dutch dictionary]. Nijhoff, The Hague.

Chao, C.-Y. 2008. A microregional approach to the social dynamics in the Late Prehistoric Manatuto, East Timor, 11th-18th century. Unpublished PhD thesis. University of Washington, Seattle.

Collins, James T. 2003. Asilulu-English Dictionary. Jakarta: Badan Penyelenggaraan Seri Nusa, Universitas Katolik Indonesia Atma Jaya.

Dempwolff, O. 1938. Vergleichende Lautlehre des austronesischen Wortschatzes, Band 3: Austronesisches Wörterverzeichnis. Dietrich Reimer, Berlin.

De Vries, J.H. 1900. Reis door eenige eilanden-groepen der Residentie Amboina. Tijdschrift van het Nederlandsch Aardrijkskundig Genootschap (2)XVII:467-502, 593-620.

Drabbe, P. 1932a. Woordenboek der Fordaatsche taal. A.C. Nix, Bandoeng.

Drabbe, P. 1932b. Woordenboek der Jamdeensche taal. A.C. Nix, Bandoeng.

Drabbe, P. 1940. Het leven van den Tanémbarees: Ethnographische studie over het Tanémbareesche volk. E.J. Brill, Leiden.

Eigen Haard 1907. Van een kleine expeditie. Beschrijving van de 'excursie' naar Babber (Tenimbereilanden). Eigen Haard 50:794-800.

Ellen, R. 2003. On the edge of the Banda zone: Past and present in the social organization of a Moluccan trading network. University of Hawai'i Press, Honolulu. doi.org/10.1515/9780824844608.

Forbes, H.O. 1885. A naturalist's wanderings in the Eastern Archipelago: A narrative of travel and exploration from 1878 to 1883. Sampson, Low, Marston, Searle and Rivington, London. doi.org/ 10.5962/bhl.title.36489.

Geurtjens, H. 1921a. Uit een Vreemde Wereld of het Leven en Streven der Inlanders op de Kei-eilanden. Teulings 's Hertogenbosch. 
Geurtjens, H. 1921b. Spraakleer der Keieesche Taal. Albrecht and Martinus Nijhoff, Weltevreden and 's Gravenhage.

Handoko, W. 2016. Situs pulau ujir di kepulauan Aru: Kampung kuno, islamisasi dan perdagangan. Kapata Arkeologi 12(2):163-174. doi.org/10.24832/kapata.v12i2.309.

Hull, G. 1998. The basic lexical affinities of Timor's Austronesian languages: A preliminary investigation. Studies in Languages and Cultures of East Timor 1:97-202.

Jacobsen, J.A. 1896. Reise in die Inselwelt des Banda-Meeres. Verlag von Mitscher and Röstell, Berlin.

Jonker, J.C.G. 1908. Rottineesch-Hollandsch Woordenboek. E.J. Brill, Leiden.

Jonker, J.C.G. 1932. Lettineesche Taalstudiën. A.C. Nix, Bandoeng.

Josselin de Jong, J.P.B. 1937. Studies in Indonesian culture I: Oirata, a Timorese Settlement on Kisar. Noord Hollandsche Uitgevers Maatschappij, Amsterdam.

Josselin de Jong, J.P.B. 1947. Studies in Indonesian culture II: The community of Erai (Wetar) (texts and notes). Noord-Hollandsche Uitgevers-Maatschappij, Amsterdam.

Josselin de Jong, J.P.B. 1987. Wetan fieldnotes: Some eastern Indonesian texts with linguistic notes and a vocabulary. Foris Publications, Dordrecht.

Kealy, S., L. Wattimena and S. O’Connor 2018. A geological and spatial approach to prehistoric archaeological surveys on small islands: Case studies from Maluku Barat Daya, Indonesia. Kapata Arkeologi 14(1):1-14. doi.org/10.24832/kapata.v13i2.458.

Kolff, D.H. 1828. Reize door den weinig bekenden zuidelijken Molukschen archipel en langs de geheel onbekende zuidwest kust van Nieuw-Guinea, gedaan in de jaren 1825 en 1826. Bij G.I.A. Beijerinck, Amsterdam.

Lape, P.V. 2006. Chronology of fortified settlements in East Timor. Journal of Island and Coastal Archaeology 1(2):285-297. doi.org/10.1080/15564890600939409.

Lape, P.V. and C.-Y. Chao 2008. Fortification as a human response to late Holocene climate change in East Timor. Archaeology in Oceania 43(1):11-21. doi.org/10.1002/j.1834-4453.2008.tb00026.x.

McKinnon, S. 1991. From a shattered sun: Hierarchy, gender, and alliance in the Tanimbar Islands. University of Wisconsin Press, Madison.

McWilliam, A. 1996. Severed heads that germinate the state: History, politics, and headhunting in Southwest Timor. In J. Hoskins (ed.), Headhunting and the social imagination in Southeast Asia, pp. 127-166. Stanford University Press, Stanford.

McWilliam, A. 2007. Austronesians in linguistic disguise: Fataluku cultural fusion in East Timor. Journal of Southeast Asian Studies 38(2):355-375. doi.org/10.1017/s0022463407000082.

Merton, H. 1910. Ergebnisse einer Zoologischen Forschungsreise in den Südöstlichen Molukken (Aruund Kei-Inseln) im Auftrag der Senckenbergischen Naturforschenden Gesellschaft. Senckenbergische Naturforschende Gesellschaft, Frankfurt am Main.

Middelkoop, P. n.d. Nederlands-Timorees Woordenboek. Unpublished manuscript. KITLV, Leiden.

Morris, C. 1984. Tetun-English dictionary. Canberra: Pacific Linguistics.

Nunn, P. 2007. Climate, environment and society in the Pacific during the last millennium. University of the South Pacific, Suva, Fiji.

O'Connor, S., M. Spriggs and P. Veth 2007. The archaeology of the Aru Islands, Eastern Indonesia. Terra Australis 22. ANU E Press, Canberra. doi.org/10.22459/ta22.2007. 
O'Connor, S., A. McWilliam, J.N. Fenner and S. Brockwell 2012. Examining the origin of fortifications in East Timor: Social and environmental factors. The Journal of Island and Coastal Archaeology 7(2):200-218. doi.org/10.1080/15564894.2011.619245.

Onvlee, L., U.H. Kapita and P.J. Luijendijk 1984. Kamberaas (Oost-Soembaas)-Nederlands woordenboek: met Nederlands-Kamberaas register. Foris, Dordrecht.

Pampus, K.-H. 1999. Koda Kiwa: Dreisprachiges Wörterbuch des Lamaholot (Dialekt von Lewolema). Franz Steiner, Stuttgart.

Pannell, S. 1991. Narrative boundaries, national horizons: The politics of identity in Amaya, Maluku Tenggara, Indonesia. PhD thesis. University of Adelaide, Adelaide.

Pannell, S. 2007. Of gods and monsters: Indigenous sea cosmologies, promiscuous geographies and the depths of local sovereignty. In P. Boomgaard (ed.), A world of water: Rain, rivers and seas in Southeast Asian histories, pp. 103-124. KITLV Press, Leiden. doi.org/10.1163/9789004254015_004.

Penn, D. 2006. Introducing Dadu'a: Uma línguade Timor-Leste. Honours Thesis. University of New England, Armidale.

Riedel, J.G.F. 1886. De sluik-en kroesharige rassen tusschenSelebes en Papua. Nijhoff., 's Gravenhage.

Samely, U. and R.H. Barnes 2013. A dictionary of the Kedang language: Kedang-Indonesian-English. Brill, Leiden.

Schapper, A. 2017. Introduction to the Papuan languages of Timor, Alor and Pantar. In A. Schapper (ed.), Papuan languages of Timor, Alor and Pantar. Sketch grammars. Volume 2, pp. 1-54. De Gruyter Mouton, Berlin. doi.org/10.1515/9781614519027-001.

Schapper, A. 2018. Life and times in Ujir: A community sourcebook. Yayasan Pustaka Obor, Jakarta.

Schapper, A. 2019. Build the wall! Village fortification, its timing and triggers in southern Maluku. Indonesia and the Malay World 47(138):220-251. doi.org/10.1080/13639811.2019.1554778.

Schapper, A., J. Huber and A. van Engelenhoven 2014. The relatedness of Timor-Kisar and Alor-Pantar languages: A preliminary demonstration. In M. Klamer (ed.), Alor-Pantar languages: History and typology, pp. 99-154. Language Science Press, Berlin. doi.org/10.26530/oapen_533875.

Tijdschrift voor Nederlandsch Indië 1858. Aroe-eilanden, in vroeger tijd en tegenwoordig. Tijdschrift voor Nederlandsch Indië 20:257-275.

van Dijk, T. 2000. Gouden eiland in de Bandazee: Socio-kosmische ideeën op Marsela, Maluku Tenggara, Indonesië. Unpublished $\mathrm{PhD}$ thesis. Leiden University, Leiden.

van Dijk, T. and N. de Jonge 1987. The house on the hill: Moieties and double descent in Babar. Bijdragen tot de Taal-, Land-en Volkenkunde 143(1):54-104. doi.org/10.1163/22134379-90003341.

Veloso, A. 2016. A grammar sketch of Naueti, a language of East Timor. MA thesis. Leiden University, Leiden.

Verheijen, J.A.J. 1967. Kamus Manggarai: Manggarai-Indonesia and Indonesia-Manggarai. Volume 1. Nijhoff, 's Gravenhage.

VOC Archives. VOC 3864, Banda, Secret letters, Report, Banda to Batavia, 4-6-1789, \$12. 
This text is taken from Forts and Fortification in Wallacea: Archaeological and Ethnohistoric Investigations, edited by Sue O'Connor, Andrew McWilliam and Sally Brockwell, published 2020 by ANU Press, The Australian National University, Canberra, Australia.

doi.org/10.22459/TA53.2020.10 